\title{
Carbon, nitrogen and phosphorus resource supply and utilisation for coastal planktonic heterotrophic bacteria in a gradient of nutrient loading
}

\author{
Olav Vadstein ${ }^{1, *}$, Tom Andersen ${ }^{2}$, Helge R. Reinertsen ${ }^{3}$, Yngvar Olsen ${ }^{3}$ \\ ${ }^{1}$ Department of Biotechnology, and ${ }^{3}$ Department of Biology, Norwegian University of Science and Technology (NTNU), \\ 7491 Trondheim, Norway \\ ${ }^{2}$ University of Oslo, Department of Biology, PO Box 1066 Blindern, 0316 Oslo, Norway
}

\begin{abstract}
Data from 7 mesocosms with a gradient in daily nutrient loading rate $\left(L_{\mathrm{N}}\right)$ and inverse modelling were used to estimate all $\mathrm{C}, \mathrm{N}$ and $\mathrm{P}$ flows in an idealised food web. The gradient in $L_{\mathrm{N}}$ created autotrophic production (AP) of 7 to $314 \mu \mathrm{g} \mathrm{Cl}^{-1} \mathrm{~d}^{-1}$ (mean values over $18 \mathrm{~d}$ ). The production of dissolved organic C (DOC) decreased from 240 to $40 \%$ of AP, and was dominated by heterotrophs (80 to $58 \%$ ), with heterotrophic bacteria (BAC) producing $48 \pm 8 \%$ (means $\pm \mathrm{SD}$ ) by excretion or lysis. The consumption of DOC by BAC was 133 to $86 \%$ of AP, and DOC accumulated when experimental $L_{\mathrm{N}} \geq$ natural $L_{\mathrm{N}}$. C of BAC origin constituted 5.5 to $0.2 \%$ of the C consumed by copepods. The production of dissolved $\mathrm{N}$ and $\mathrm{P}$ was mainly by heterotrophs $(92 \pm 2 \%$ of DN, $92 \pm$ $4 \% \mathrm{DP}$ ), but autotrophs produced $26 \pm 7 \%$ of dissolved organic N (DON) and $21 \pm 8 \%$ of dissolved organic P (DOP). For the production of inorganic N and P (DIN and DIP, respectively), BAC predators produced $>50 \%$ of DIN and $>70 \%$ of DIP at low or moderate $L_{\mathrm{N}}$ (averages $37 \pm 16 \%$ of DIN and $66 \pm 14 \%$ of DIP). The contribution by BAC was low for DIN (12 $\pm 6 \%$ ) and zero for DIP. For the re-mineralisation of $\mathrm{N}$ and $\mathrm{P}$, the significance of $\mathrm{BAC}$ was as $\mathrm{N}$ and $\mathrm{P}$ rich food particles. DOP accumulated more than DOC, despite the high demand for P. Turnover time of dissolved organic matter (DOM) decreased from around 80 to $12 \mathrm{~d}$ with increasing $L_{\mathrm{N}}$. These data provide new insights into the role of various functional groups of organisms for the cycling of DOM, and to the differences in $\mathrm{C}, \mathrm{N}$ and $\mathrm{P}$ cycling.
\end{abstract}

KEY WORDS: DOM production - DOM utilisation - Heterotrophic bacteria · Community interactions $\cdot$ DOC accumulation $\cdot$ Re-mineralisation $\cdot$ Inverse modelling

\section{INTRODUCTION}

Research in the last 3 decades has overthrown the paradigm of heterotrophic Bacteria and Archaea (hereafter called heterotrophic bacteria or BAC) as numerically insignificant, inactive, and 'altruistic' in terms of re-mineralisation of inorganic nutrients for autotrophs (Azam et al. 1983, Vadstein 2000, Sherr \& Sherr 2008). However, this new paradigm has so far been applied mainly to inform our understanding of the cycling of carbon $(\mathrm{C})$ and to a much lesser extent to the cycling of nitrogen $(\mathrm{N})$ and phosphorus $(\mathrm{P})$, in spite of the fact that $\mathrm{N}$ and $\mathrm{P}$ often limit system productivity (Elser et al. 2007). For both marine and limnetic systems, a large number of studies have revealed the significance of planktonic heterotrophic bacteria as standing biomass, as producers that convert dissolved organic matter (DOM) to particles available for predators in the food web, and as a main contributor to community respiration (see e.g. Kirchman 2008). Furthermore, it seems that mineral nutrient limitation is as normal as carbon/energy limita- 
tion, and bacteria have a fundamental role in the cycling of mineral nutrients both as competitor consumers and as prey (Vadstein 2000, Church 2008). It has moreover been shown that grazing and viral infections are dominating mortality factors, and that protozoa are the most important grazers in marine systems (Breibart et al. 2008, Jürgens \& Massana 2008).

However, many key processes are poorly studied, such as the supply and utilisation of resources, biomass development and fate, and the functional role of heterotrophic bacteria in the planktonic food web. This is to a large extent because methods to undertake such studies either do not exist or are extremely time consuming. As a consequence, many systems are under-studied, and to obtain a more complete picture, the missing rates need to be calculated based on data from other sources. Normally, such calculations are done using fixed values found in the literature (e.g. Vadstein et al. 1989, 1993). However, characteristics such as growth yield and clearance rate are variables and not fixed parameters (Pirt 1982, Børsheim \& Olsen 1984), and therefore the calculations may end up as products of our own misconceptions.

An alternative approach for handling the dilemma of under-studied systems is inverse modelling, where rates are calculated based on input data and constraints on unknown variable or parameter values (Vézina \& Platt 1988). Thus, instead of setting fixed values for an unknown characteristic, a range constraining possible values is set, which may reflect the total range given in the literature (e.g. see Table 3). Thus, inverse modelling is a less biased method than traditional budget calculations and can end up challenging the investigator's prejudices (see 'Results'). Inverse modelling has previously been applied with success in several studies of planktonic systems (e.g. Jackson \& Eldridge 1992, Stone et al. 1993, Olsen et al. 2006, 2007, 2011, Kones et al. 2006, van Oevelen et al. 2010).

Examples of questions that have yet to be answered regarding the ecological role of planktonic heterotrophic bacteria are

- Which organisms supply the dissolved organic C (DOC) and organic and inorganic $\mathrm{N}$ and $\mathrm{P}$ resources that heterotrophic bacteria rely on for growth?

- How large a share of primary production ends up as DOC and how much of this is taken up by heterotrophic bacteria?

- What is the fate of the DOC taken up by bacteria and of the heterotrophic bacterial biomass, and to what extent do heterotrophic bacteria contribute to $\mathrm{C}$ flow up in the planktonic food web?
- How efficiently do heterotrophic bacteria utilise $\mathrm{C}, \mathrm{N}$ and $\mathrm{P}$ taken up for the production of new biomass?

- To what extent do heterotrophic bacteria utilise inorganic versus organic $\mathrm{N}$ and $\mathrm{P}$ resources, and are they net re-mineralisers of $\mathrm{N}$ and $\mathrm{P}$ ?

- Do DOC and dissolved organic N and P (DON and DOP, respectively) accumulate due to higher production than consumption, and what is the turnover time of these resources?

- Are C, N and P budgets proportionally identical, but differentially scaled representations, or do the 3 elements show specific characteristics?

There are likely no general answers to the above questions, as processes will be influenced by system characteristics. As a consequence, studies done in environmental gradients, either natural or experimental, may provide more general conclusions than studies at a single site.

The objective of the present paper was to address the above questions regarding resource supply and utilisation in an experimental gradient of nutrient inputs to coastal waters. The main focus was on biological flows that are currently hard or impossible to quantify directly. Data were derived from a comprehensive mesocosm experiment designed to provide data sets suitable for inverse modelling of $\mathrm{C}, \mathrm{N}$ and $\mathrm{P}$ flows, covering a wide gradient of nutrient loadings. The food web components were assigned to 3 functional autotrophic groups based on size and 4 heterotroph groups based on trophic position and size, of which the heterotrophic bacteria (BAC) were one (Fig. 1). We used inverse modelling (i.e. Vézina \& Platt 1988) to reconstruct 30 flows in the investigated coastal planktonic food web (Fig. 1). From this very comprehensive experiment, 4 previous papers have reported on zooplankton development (Gismervik et al. 2002), primary production, carbohydrate production and release (Børsheim et al. 2005), zooplanktonmediated flows of carbon (Olsen et al. 2007) and the limiting factors of heterotrophs (Olsen et al. 2011).

\section{MATERIALS AND METHODS}

\section{Experimental design and operation}

Data for the estimation of plankton biomasses and major flows with variable nutrient input were obtained from 7 large mesocosms (12 m deep, volume $38 \mathrm{~m}^{3}$ ) suspended in a pristine lagoon on the west coast of central Norway (Hopavågen, 633 $35^{\prime} 38^{\prime \prime} \mathrm{N}$, $9^{\circ} 32^{\prime} 48^{\prime \prime}$ E). The system has typical summer chloro- 


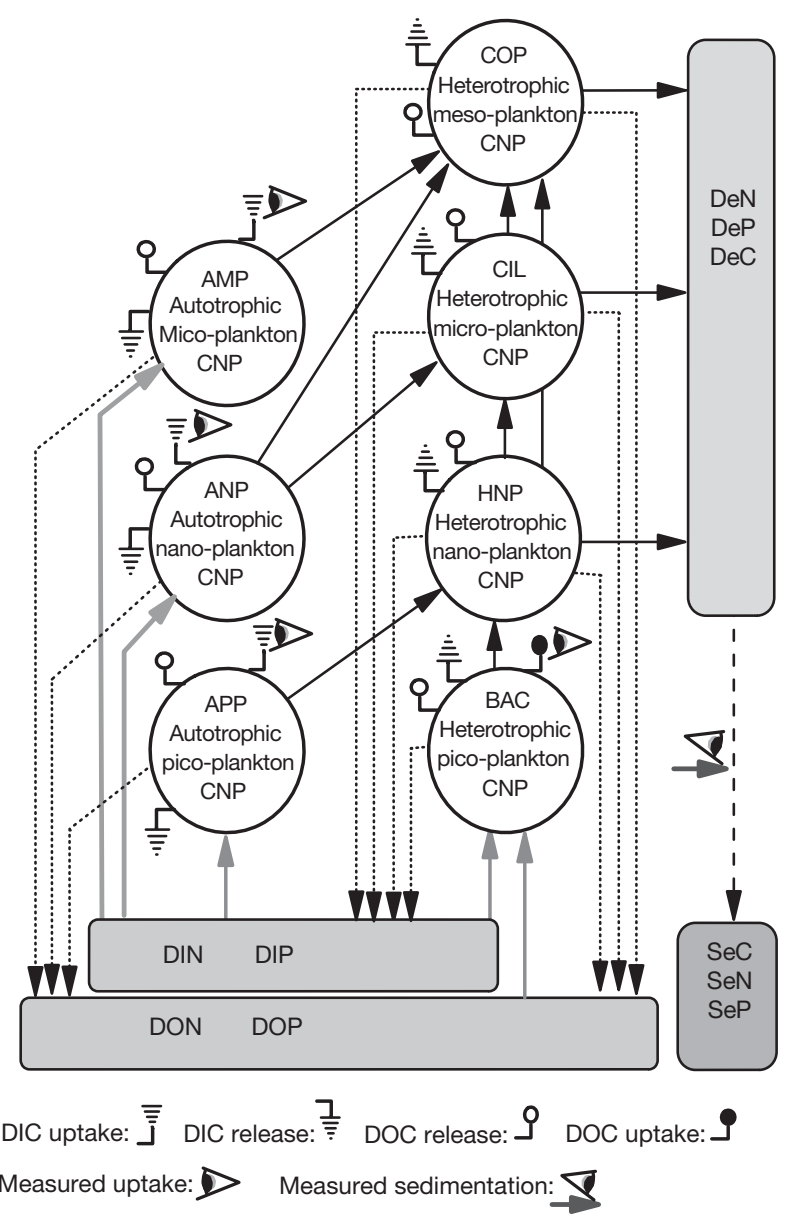

Fig. 1. Flow network forming the framework for food web C, $\mathrm{N}$ and $\mathrm{P}$ biomass determination and flow estimates by inverse modelling. DeC, DeN, DeP: detrital particulate, DIC, DIN, DIP: dissolved inorganic, DOC, DON, DOP: dissolved organic, SeC, SeN and SeP: sedimentation rate, each with C, $\mathrm{N}$ and $\mathrm{P}$, respectively. See Table 2 for further abbreviations and details of functional groups

phyll a concentrations of 1 to $3 \mu g \mathrm{l}^{-1}$ (unpubl.). Pelagic waters containing the natural plankton community were enclosed by sinking and carefully lifting the mesocosms from a depth of $12 \mathrm{~m}$. The temperature in the mesocosms ranged from 15 to $16^{\circ} \mathrm{C}$ and the salinity was $31 \pm 1$ ppt (mean $\pm \mathrm{SD}$ ). The experiment was a single-factor experiment (variable nutrient dose, balanced $\mathrm{N}: \mathrm{P}: \mathrm{Si}$ ) run for 18 d (19 August to 5 September, 1997). The nutrient doses added (Table 1) formed an exponential series, and the intention was that the highest dose should result in some degree of saturation of the autotrophic response. Mesocosm 3 was provided nutrients in amounts comparable to the estimated average natural supply to the lagoon system (unpubl.). The nutrient mixture was added daily after sam-
Table 1. Daily nutrient addition rates used in the experiment. Elemental ratios for N:Si:P were 16:16:1, and doses from Mesocosms 2 to 7 increased exponentially (factor 1.7). Mesocosm 1 received no additions (control). Mesocosm 3 received $\mathrm{N}$ and $\mathrm{P}$ doses believed to be similar to the natural dose of the system. $\mathrm{N}$ was added as $\mathrm{NH}_{4} \mathrm{NO}_{3}(50 \% \mathrm{~N}$ as $\mathrm{NO}_{3}{ }^{-}$and $50 \% \mathrm{~N}$ as $\mathrm{NH}_{4}{ }^{+}$), $\mathrm{P}$ as $\mathrm{Na}_{2} \mathrm{HPO}_{4}$, and $\mathrm{Si}$ as $\mathrm{SiO}_{2}$

\begin{tabular}{|lccc|}
\hline \multirow{2}{*}{ Mesocosm } & $\mathrm{N}$ & $\mathrm{P}$ & $\mathrm{Si}$ \\
\cline { 2 - 4 } & & $\left(\mathrm{mg} \mathrm{m}^{-3} \mathrm{~d}^{-1}\right)$ & \\
\hline 1 & 0 & 0 & 0 \\
2 & 2.13 & 0.29 & 4.27 \\
3 & 3.61 & 0.50 & 7.25 \\
4 & 6.14 & 0.85 & 12.33 \\
5 & 10.4 & 1.45 & 21.0 \\
6 & 17.8 & 2.46 & 35.6 \\
7 & 30.2 & 4.18 & 60.6 \\
\hline
\end{tabular}

pling with a method that secured efficient distribution and mixing of the nutrients.

\section{Sampling, determination of biomass and analytical methods}

Integrated water samples ( 0 to $10 \mathrm{~m}$ depth) were collected daily (06:00 to 08:30 h) with a Ramberg sampler (2 m length, 4.21 volume), transferred to 251 light-protected containers, and sub-sampled for analysis of plankton and chemical components. Separate integrated meso-zooplankon samples were collected from the mesocosms in the afternoon every second day, and concentrated on a $35 \mu \mathrm{m}$ net before further treatment. Methods of preservation, counting and estimation of carbon biomass of the plankton organisms assigned to the functional groups are reviewed in Table 2 (details in Olsen et al. 2007).

Particulate C, N and P in the fractions $(<200,<20$ and $<1 \mu \mathrm{m}$ ) were measured by standard methods after successive size fractionation through 200 and $20 \mu \mathrm{m}$ nylon screens and $1 \mu \mathrm{m}$ Nuclepore filters (Olsen et al. 2007). Dissolved inorganic (nitrate, ammonium, phosphate and silica) and organic (DOC, DON and DOP) nutrients were measured in GF/F filtered water (Olsen et al. 2007). Detrital C, N and P $(<200 \mu \mathrm{m})$ was calculated as the difference between measured particulate $\mathrm{C}, \mathrm{N}$ and $\mathrm{P}$ and the sum of $\mathrm{C}, \mathrm{N}$ and $\mathrm{P}$ in the biotic components. Estimation of $\mathrm{N}$ and $\mathrm{P}$ content in biomass of the functional components was based on measured $\mathrm{C}, \mathrm{N}$ and $\mathrm{P}$ in the particulate fractions $(<200,<20$ and $<1 \mu \mathrm{m})$ and mass balance. The average estimated $\mathrm{N}: \mathrm{C}\left(Q_{\mathrm{N}}\right)$ and P:C $\left(Q_{\mathrm{P}}\right)$ are shown in Table 2 . The $Q_{\mathrm{P}}$ value for BAC was based on the $\mathrm{P}$ concentration in the $<1 \mu \mathrm{m}$ fraction, with $\mathrm{P}$ in 
Table 2. Principal methods for estimation of carbon biomass and estimated mean nutrient ratios $\left(Q_{i}\right.$ i.e. N:C and P:C ratios) of food web components (functional groups). Samples were taken each second day (see text). FNC: flow network construction; BB: biovolume based carbon estimate; LB: length based carbon estimate; MS: obtained by microscopy or epifluorescence microscopy; IA: obtained with an image analysing system (Macintosh computer and the image processing program IP Lab); fc: final concentration

\begin{tabular}{|c|c|c|c|c|}
\hline \multirow{2}{*}{$\begin{array}{l}\text { Food web } \\
\text { component } \\
\text { (functional group) }\end{array}$} & \multirow[t]{2}{*}{$\begin{array}{l}\text { Sedation, preserving, } \\
\text { and staining of samples }\end{array}$} & \multirow[t]{2}{*}{$\begin{array}{l}\text { Dominant taxonomic groups and method used } \\
\text { for biomass determination }\end{array}$} & \multicolumn{2}{|c|}{$\begin{array}{l}Q \text { used for FNC } \\
\quad\left(\mu \mathrm{g} \mathrm{mg} \mathrm{C} \mathrm{C}^{-1}\right)\end{array}$} \\
\hline & & & & \\
\hline Pico-autotrophs & $\begin{array}{l}0.5 \text { mmol EDTA } 1^{-1}(\mathrm{fc}) \\
\text { Glutaraldehyde }(1 \% \mathrm{fc})\end{array}$ & $\begin{array}{l}\text { Pico-cyanobacteria, <2 } \mu \mathrm{m}, \mathrm{BB}-\mathrm{IA}, 0.21 \mathrm{pg} \\
\mathrm{C} \mu \mathrm{m}^{-3} \text { (Booth 1993) }\end{array}$ & $\begin{array}{l}\mathrm{N}: \mathrm{C} \\
\mathrm{P}: \mathrm{C}\end{array}$ & $\begin{array}{c}250 \\
20\end{array}$ \\
\hline \multicolumn{5}{|c|}{ 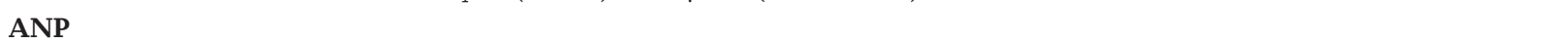 } \\
\hline Nano-autotrophs & Acid Lugol's (1 \% fc) & $\begin{array}{l}\text { Diatoms }<20 \mu \mathrm{m} \text {, autotrophic flagellates, small } \\
\text { dinoflagellates }<20 \mu \mathrm{m}, \mathrm{BB}-\mathrm{MS} \text {, group-specific } \\
\text { regressions (Strathmann 1967) }\end{array}$ & $\begin{array}{l}\mathrm{N}: \mathrm{C} \\
\mathrm{P}: \mathrm{C}\end{array}$ & $\begin{array}{c}170 \\
15\end{array}$ \\
\hline \multicolumn{5}{|c|}{$\int_{0}$} \\
\hline Micro-autotrophs & Acid Lugol's (1 \% fc) & $\begin{array}{l}\text { Diatom colonies, dinoflagellates, autotrophic ciliates, } \\
\text { BB-MS, group-specific regressions (Strathmann 1967) }\end{array}$ & $\begin{array}{l}\mathrm{N}: \mathrm{C} \\
\mathrm{P}: \mathrm{C}\end{array}$ & $\begin{array}{c}150 \\
15\end{array}$ \\
\hline \multicolumn{5}{|l|}{ BAC } \\
\hline Pico-heterotrophs & 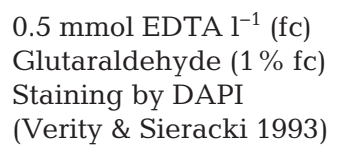 & $\begin{array}{l}\text { Bacteria (and Archaea), }<1 \mu \mathrm{m}, \mathrm{BB}-\mathrm{IA}, 0.16 \mathrm{pg} \mathrm{C} \mu \mathrm{m}^{-3} \\
\text { (Vadstein \& Olsen 1989) }\end{array}$ & $\begin{array}{l}N: C \\
P: C\end{array}$ & $\begin{array}{c}250 \\
75\end{array}$ \\
\hline \multicolumn{5}{|l|}{ HNP } \\
\hline Nano-heterotrophs & $\begin{array}{l}0.5 \text { mmol EDTA } 1^{-1} \text { (fc) } \\
\text { Glutaraldehyde }(1 \% \text { fc) } \\
\text { Staining by DAPI } \\
\text { (Verity \& Sieracki 1993) }\end{array}$ & $\begin{array}{l}\text { Heterotrophic nanoflagellates (HNF) } 2 \text { to } 8 \mu \mathrm{m}, \\
\text { bacterivore ciliates, appendicularia, BB-IA, } \\
0.22 \text { pg C } \mathrm{m}^{-3} \text { (Børsheim \& Bratbak 1987, } \\
\text { Gismervik et al. 2002) }\end{array}$ & $\begin{array}{l}\mathrm{N}: \mathrm{C} \\
\mathrm{P}: \mathrm{C}\end{array}$ & $\begin{array}{c}180 \\
21\end{array}$ \\
\hline \multicolumn{5}{|c|}{ 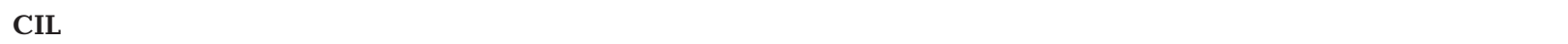 } \\
\hline Micro-heterotrophs & Acid Lugol's (2\% fc) & $\begin{array}{l}\text { Ciliates, } 20 \text { to } 50 \mu \mathrm{m}, \mathrm{BB}-\mathrm{MS}, 0.20 \mathrm{pg} \mathrm{C} \mu \mathrm{m}^{-3} \\
\text { (Putt \& Stoecker 1989). }\end{array}$ & $\begin{array}{l}\mathrm{N}: \mathrm{C} \\
\mathrm{P}: \mathrm{C}\end{array}$ & $\begin{array}{c}230 \\
31\end{array}$ \\
\hline $\begin{array}{l}\text { COP } \\
\text { Meso-heterotrophs }\end{array}$ & Acid Lugol's (1\% fc) & $\begin{array}{l}\text { Calanoid and cyclopoid copepods, cladocera, LB-MS, } \\
\text { group-specific regressions (Gismervik et al. 2002) }\end{array}$ & $\begin{array}{l}N: C \\
P: C\end{array}$ & $\begin{array}{c}180 \\
34\end{array}$ \\
\hline
\end{tabular}

picocyanobacteria (APP) subtracted. The $Q_{\mathrm{P}}$ of BAC was 2.5 times higher than the subsistence quota for bacteria and considerably below the saturation level (Vadstein 2000).

\section{Rate measurements}

Samples for the measurement of primary and bacterial production were taken from the container immediately after sampling. Primary production was measured by the ${ }^{14} \mathrm{C}$-method and bacterial production by the thymidine incorporation method. Radioactive bicarbonate $\left(\mathrm{H}^{14} \mathrm{CO}^{3-}\right.$, $3.6 \mu \mathrm{Ci}$ bottle ${ }^{-1}$; International Agency for ${ }^{14} \mathrm{C}$ Determination) was added to the mixed sample $(0$ to $10 \mathrm{~m})$ from each mesocosm after transfer to replicate transparent bottles $(63 \mathrm{ml}$, Nunc) and 1 dark bottle per mesocosm. Samples were incubated at a depth of $2 \mathrm{~m}$ in situ for $4 \mathrm{~h}$ at midday. After termination, water samples were successively fractionated (20-200 $\mu \mathrm{m}, 1-20 \mu \mathrm{m}$ and $0.2-1 \mu \mathrm{m})$ using a vacuum filtration unit. The radioactivity was measured in a scintillation counter (Pacard Tri-Carb 1900). Daily rates were estimated based on a light factor (photosynthetic active radiation [PAR] during $24 \mathrm{~h}$ divided by PAR during the incubation), and further converted to average volumetric rates based on independent control experiments. Control experiments revealed that there was a good correspondence between integrated daily production and estimates based on $4 \mathrm{~h}$ incubations and the light factor, and that incubations at $2 \mathrm{~m}$ depth were representative for the $10 \mathrm{~m}$ water column in the mesocosms (Børsheim et al. 2005). The standard error of the mean of the primary production determinations were $2.8 \%$.

Bacterial production was measured according to Bell (1993) by adding $20 \mathrm{nM}$ of methyl-( $\left.{ }^{3} \mathrm{H}\right)$-thymidine 
to replicate mixed samples $(20 \mathrm{ml})$. The incubations $(1 \mathrm{~h}$, in situ temperature) were stopped by adding formaldehyde (final concentration $1 \%$ ), whereas a control sample was stopped at time zero. Samples were filtered on $0.2 \mu \mathrm{m}$ cellulose acetate membranes, and macromolecules were precipitated by adding 5 $\mathrm{ml}$ ice cold TCA (10\%) 3 times. ${ }^{3} \mathrm{H}$ activity was measured by liquid scintillation counting, and corrected for background in pre-fixed samples. Thymidine incorporation into cold TCA insoluble material was converted to production with a conversion factor of $2.0 \times 10^{18} \mathrm{cells} \mathrm{mol}^{-1}$ (Bell 1993). Bacterial carbon production was estimated by multiplying by $\mathrm{C}$ per cell, which was calculated from volume estimates determined by epifluorescence microscopy and image analysis. The volume to $\mathrm{C}$ conversion factor used was

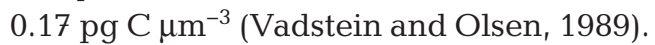

Sedimentation rates of $\mathrm{P}$ were estimated as the difference between the accumulated daily added $\mathrm{P}$ (Table 1) and measured total $P$ which accumulated in the water. This means that added $\mathrm{P}$ could either accumulate in the water or in the sediments. The sedimentation rates of $\mathrm{C}$ and $\mathrm{N}$ were estimated based on the $\mathrm{P}$ sedimentation rates and the elemental ratios ( $\mathrm{P}: \mathrm{C}$ and $\mathrm{P}: \mathrm{N})$ of material collected in sedimentation traps. The traps were suspended at $9 \mathrm{~m}$ depth and harvested every fourth day. The sedimentation rates obtained directly from the traps agreed well with those estimated by mass balance, but were more variable.

\section{Flow network characteristics and construction}

The methods of inverse modelling used are presented and discussed by Olsen et al. (2006, 2007, 2011). Our simplified planktonic food web that formed the framework for the flow network construction in the mesocosm communities (Fig. 1) included 3 functional autotrophic components, 4 heterotrophic, and 30 inter-compartmental C flows. All components and flows had an analogous $\mathrm{N}$ and $\mathrm{P}$ term (Fig. 1). The input data for the flow network construction was time series data ( 7 mesocosms, 10 sampling days) of carbon biomass of the 7 functional groups, the corresponding $\mathrm{N}$ and $\mathrm{P}$ in the biomass, concentrations of inorganic $\mathrm{N}$ and $\mathrm{P}$, concentrations of dissolved organic $\mathrm{C}, \mathrm{N}$ and $\mathrm{P}$, concentrations of detrital particulate $\mathrm{C}, \mathrm{N}$ and $\mathrm{P}$, primary production in 3 size fractions corresponding to the 3 autotrophic functional components, bacterial production, and sedimentation rate of $\mathrm{C}, \mathrm{N}$ and $\mathrm{P}$ (Fig. 1). A total of 4410 measured or estimated concentrations and 490 measured flows were included in the calculations. In addition, fairly broad constraining rules were used in the calculations (Table 3).

The flow network construction process generated a complete set of food web flows representing mean flows for the $18 \mathrm{~d}$ period of each mesocosm, with independent calculations for each unit. The uptake of $\mathrm{N}$ and $\mathrm{P}$ (or ingestion) by heterotrophs was linked to the $\mathrm{C}$ uptake flows. The constraining factors involved no other strong link between the $\mathrm{C}$ flows and the flows of $\mathrm{N}$ and $\mathrm{P}$. The estimated flows are means of 1000 Monte Carlo simulations for each of the following conditions: 'Only- $\mathrm{C}$ ', 'C and $\mathrm{N}$ ' and ' $\mathrm{C}$ and $\mathrm{P}$ '. The Monte Carlo simulations included all measured variability of the input data (concentrations, biomasses, flow measurements), and allowed for an estimation of confidence limits for the flows. The estimated C flows were almost identical for only-C and with $\mathrm{N}$ and $\mathrm{P}$ linked to $\mathrm{C}\left(\mathrm{r}^{2}=0.9999\right)$, and full rank solutions were obtained for all mesocosms. More systematic uncertainty was related to the relevance of the basic structure of the flow network, the quality of the input data and the constraining windows (Table 3). Consult Olsen et al. $(2007,2011)$ for a general discussion of the inverse solutions of the experiment.

\section{Calculations based on constructed flow-networks}

Maximum and minimum estimates were obtained for growth efficiency (GE) for BAC. The maximum estimate assumed that the flux of $\mathrm{C}$ from $\mathrm{BAC}$ to DOC was entirely due to lysis by viruses (this organic $\mathrm{C}$ was part of the production), whereas the minimum estimate assumed that the flux from BAC to DOC was wholly excretion (this organic $\mathrm{C}$ was a loss and treated similarly to respiration). Percent re-mineralisation of $\mathrm{N}$ and $\mathrm{P}$, defined as the net release of DIN and DIP normalised to consumed DON and DOP, respectively, was calculated as the difference between release and uptake of DIN and DIP divided by the uptake of DON and DOP, respectively, and multiplied by 100 . The production by BAC can be channelled up the food web and reach meso-heterotrophs (COP) via nano-heterotrophs (HNP) and micro-heterotrophs (CIL) (see Table 2 for further explanation of functional group abbreviations) through 2 (BAC $\rightarrow$ $\mathrm{HNP} \rightarrow \mathrm{COP}$; Fig. 1) or 3 trophic transfers (BAC $\rightarrow$ $\mathrm{HNP} \rightarrow \mathrm{CIL} \rightarrow \mathrm{COP} ;$ Fig. 1). The indirect importance of $\mathrm{BAC}$ production for the ingestion by COP can be calculated as a sum of $\mathrm{C}$ channelled through the 'short route' and the 'long route'. For the 'short route', the fraction of $\mathrm{C}$ of $\mathrm{BAC}$ origin ingested by $\mathrm{COP}$ was calculated as the fraction $\mathrm{BAC}$ of the total 
Table 3. Rules used to constrain flows of inverse modelling. TPP: total (gross) primary production $\left(\mu g \mathrm{C}^{-1} \mathrm{~d}^{-1}\right)$; DOC, DON, DOP: dissolved organic, DeC, DeN, DeP: detrital particulate C, N and P, respectively; DIC: dissolved inorganic C. ${ }^{\text {a Assumes }}$ that carbon is $10 \%$ of wet weight and that a specific gravity of $1 \mathrm{~kg} \mathrm{l}^{-1}$, giving $10^{5}$ body volume $\mathrm{h}^{-1}=0.02 \mathrm{l} \mu \mathrm{C}^{-1} \mathrm{~d}^{-1}$. Other abbreviations are defined in Tables 1 and 2

\begin{tabular}{|c|c|c|}
\hline Flow & Food web component & Constraint or rule (reference) \\
\hline All C flows & All & $0<$ flow $<$ max. flow \\
\hline DOC release (excretion or lysis) & $\mathrm{AMP}, \mathrm{ANP}, \mathrm{APP}$ & $(0.05-0.5) \times$ TPP (Vézina 1989) \\
\hline Specific DIC release (respiration) & $\begin{array}{l}\text { AMP, ANP, APP } \\
\text { BAC } \\
\text { HNP, CIL } \\
\text { COP }\end{array}$ & $\begin{array}{l}\geq 0.05 \mathrm{~d}^{-1} \text { (Vézina 1989) } \\
\geq 0.05 \mathrm{~d}^{-1} \text { (Vézina 1989) } \\
\geq 0.20 \mathrm{~d}^{-1} \text { (Vézina 1989) } \\
\geq 0.07 \mathrm{~d}^{-1} \text { (Vézina 1989) }\end{array}$ \\
\hline Maximum clearance rates & $\begin{array}{l}\text { HNP } \\
\text { CIL, COP }\end{array}$ & $\begin{array}{l}0.021 \mu \mathrm{g} \mathrm{C}^{-1} \mathrm{~d}^{-1} \text { (mod. from Fenchel (1982) } \\
0.021 \mu \mathrm{g} \mathrm{C}^{-1} \mathrm{~d}^{-1} \text { (Gismervik et al. 1996) }\end{array}$ \\
\hline Maximum specific ingestion rate $\left(\mathrm{I}_{\mathrm{CM}}\right)$ & $\begin{array}{l}\text { HNP } \\
\text { CIL } \\
\text { COP }\end{array}$ & $\begin{array}{l}8 \mathrm{~d}^{-1} \\
4 \mathrm{~d}^{-1} \\
2 \mathrm{~d}^{-1}\end{array}$ \\
\hline Selectivity: clearance rate (CR), $1 \mu \mathrm{g} \mathrm{C}^{-1} \mathrm{~d}^{-1}$ & $\mathrm{COP}$ & CR of $\mathrm{CIL}>\mathrm{CR}$ of AMP $>$ CR of ANP $>$ CR of HNP \\
\hline Carbon growth efficiency $\left(\mathrm{GE}_{\mathrm{C}}=\right.$ & BAC, HNP, CIL & 0.1-0.6 (Vézina 1989) \\
\hline C-growth:C-ingestion/consumption) & $\mathrm{COP}$ & <0.4 (Vézina 1989) \\
\hline Net rate of change & $\mathrm{DeC}$ & Zero for all Meso \\
\hline $\mathrm{N}$ and $\mathrm{P}$ ingestion/uptake & BAC, HNP, CIL, COP & $\mathrm{N}: \mathrm{C}$ and $\mathrm{P}: \mathrm{C}$ intake equal to food (Table 3 ) \\
\hline Released DON:DOC and DOP:DOC & $\begin{array}{l}\text { AMP, ANP, APP HNP, } \\
\text { CIL, COP }\end{array}$ & $\begin{array}{l}\mathrm{N}: \mathrm{C} \text { biomass }>\text { DON:DOC }>\mathrm{N}: \mathrm{C}_{\min } \\
\mathrm{P}: \mathrm{C} \text { biomass }>\text { DON:DOC }>\mathrm{P}: \mathrm{C}_{\min }\end{array}$ \\
\hline Released DeN:DeC and DeP:DeC & HNP, CIL, COP & $\begin{array}{l}\mathrm{N}: \mathrm{C} \text { biomass }>\text { DeN:DeC }>\mathrm{N}: \mathrm{C}_{\min } \\
\mathrm{P}: \mathrm{C} \text { biomass }>\text { DeN:DeC }>\mathrm{P}: \mathrm{C}_{\min }\end{array}$ \\
\hline $\mathrm{N}: \mathrm{C}_{\min }$ & $\begin{array}{l}\text { DON:DOC } \\
\text { DeN:DeC }\end{array}$ & $\begin{array}{l}0.05 ; 5 \% \text { percentile of measured DON:DOC } \\
\text { and DeN:DeC ratios }\end{array}$ \\
\hline $\mathrm{P}: \mathrm{C}_{\min }$ & $\begin{array}{l}\text { DOP:DOC } \\
\text { DeP:DeC }\end{array}$ & $\begin{array}{l}0.0033 ; 5 \% \text { percentile of measured } \\
\text { DOP:DOC and DeP:DeC ratios }\end{array}$ \\
\hline $\mathrm{N}, \mathrm{P}$ release and metabolic flows & $\mathrm{BAC}$ & No constraints \\
\hline
\end{tabular}

ingestion by HNP multiplied by the fraction of HNP of the total ingestion by COP. The importance of BAC C for COP through the 'long route' was calculated in a similar way as a product of 3 entities. The trophic positions on the C-basis of DOC and heterotrophic components were estimated as the column sum of the Leontief inverse (Ulanowicz, 1986). Calculations of trophic positions on an N- and P-basis were based on 2 assumptions: (1) DON and DOP released from 1 functional group have the same trophic position as the C-based trophic position of that group, and the trophic position of DON and DOP is calculated as a weighted average based on all sources. (2) DIP and DIN released from any functional group has a trophic position of zero, as for $\mathrm{CO}_{2}$, and therefore make a zero contribution to the trophic position of dissolved $\mathrm{N}$ and $\mathrm{P}$ consumed by heterotrophs. The trophic position of BAC on a N- and a P-basis was therefore calculated as the trophic position of material consumed +1 , for example for $\mathrm{N}$ : [trophic position of DON multiplied by the share of DON in the total N-uptake] +1 .

\section{RESULTS}

\section{Measured pools and rates}

No response in DIN and DIP concentrations was recorded for the 4 to 5 lowest nutrient loading rates, whereas an increase in concentration peaking at Day 5 was observed for the 2 highest loading rates (Børsheim et al. 2005, Olsen et al. 2007). From Day 9 onwards the concentrations were down to the low initial concentrations.

A clear dose-response relationship was observed in autotrophic production (Fig. 2), but with a time delay of $\sim 5 \mathrm{~d}$ from start of the experiment and until the production doubled. The maximum rate of production was observed after $\sim 9 \mathrm{~d}$, with a $>20$-fold range in production rates along the nutrient loading gradient. For the 2 highest nutrient loading rates, primary production declined to approximately half the recorded maximum by the end of the experiment, whereas production was sustained throughout the experimen- 

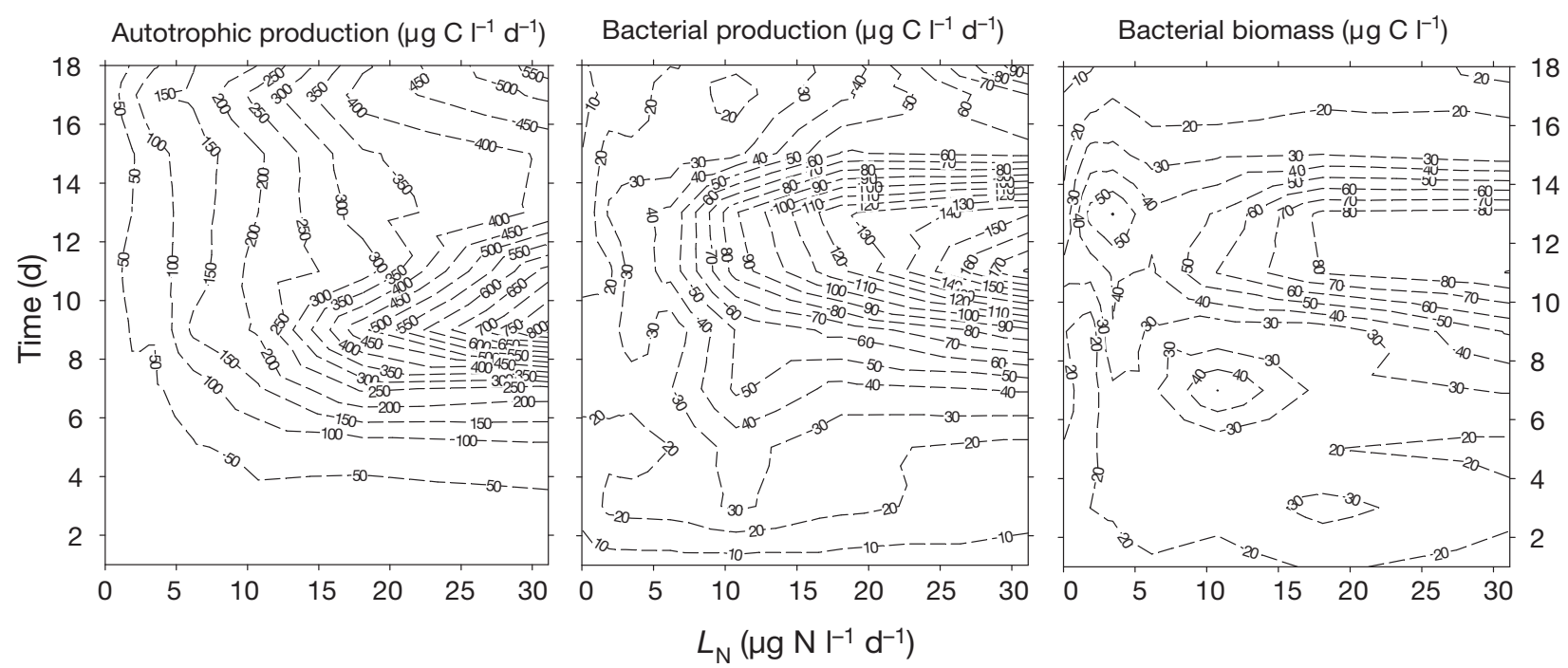

Fig. 2. Development in autotrophic production, and heterotrophic bacterial production and biomass as a function of $\mathrm{N}$ loading rate $\left(L_{N}\right)$ and time. Contour plots are based on estimates sampled on $11 \mathrm{~d}$ and at 7 different nutrient loadings

tal period for lower nutrient loading rates. BAC production developed in a similar manner, but with an $\sim 2 \mathrm{~d}$ time lag until maximum production compared to the delay in autotrophic production (Fig. 2). BAC production also showed a clear dose-response relationship, but the range during the period of maximum production spanned only a factor of 8 to 10 , and rates after the maximum decreased to only a final 2- to 4 fold increase over the starting bacterial production. Regression analyses indicated that BAC production, as a percentage of autotrophic production, decreased from 119 to $11 \%$ within the range of measured autotrophic production. Biomass and production of BAC were highly correlated $\left(F=66.97\right.$ and $\mathrm{R}^{2}=0.545$ for log-log regression), and proportional (slope of the $\log -\log$ regression $=1.03 \pm 0.13$ ). However, the untransformed values revealed that for BAC the response in biomass was smaller than the response in production (8-fold versus 20 -fold range in variation). Time course data for autotrophic and BAC production for 4 of the mesocosms are given in Børsheim et al. (2005)

The average biomass of autotrophs increased linearly and 9-fold within the loading gradient, whereas the increase in the biomass of heterotrophs showed some evidence of saturation at higher nutrient loadings and spanned only a factor of 2 (Fig. 3). This resulted in a 4 -fold change in the ratio between autoand heterotrophic biomass (range 1.6 to 6.6). For the autotrophs, the nanoplankton (ANP) increased considerably in the percentage of autotrophs with increased nutrient loading, whereas for the hetero- trophs, no comparable change was observed in the percent contribution of the different functional groups. CIL responded slightly more and COP slightly less than the other heterotrophic groups. BAC biomass as a percentage of heterotrophic biomass changed little within the gradient and averaged $29 \pm 2 \%($ mean $\pm \mathrm{SD})$. The biomass of BAC as a percentage of autotrophic and total planktonic biomass decreased inversely with the loading rate, (from 21 to $5 \%$ and 13 to $4 \%$, respectively), and with means \pm

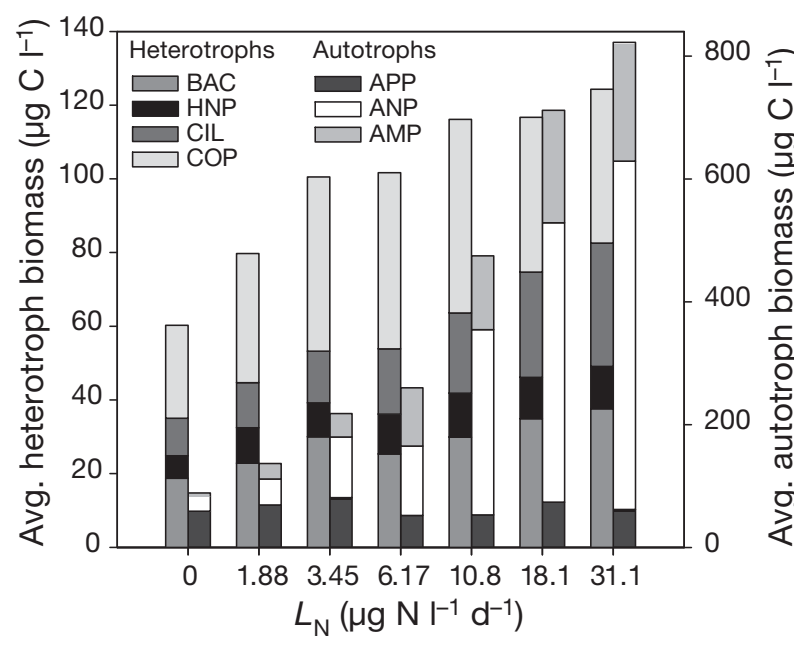

Fig. 3. Average biomass of the different functional groups (see Fig. 1) as a function of $\mathrm{N}$ loading rate $\left(L_{\mathrm{N}}\right)$, shown as stacked bars for heterotrophs (left) and autotrophs (right). Note the 6 -fold difference in the 2 biomass scales. See Table 2 for an explanation of functional group abbreviations 
Table 4. Biomass of nano-heterotrophs (HNP) feeding on heterotrophic bacteria (BAC) as a function of $\mathrm{N}$ loading rate $\left(L_{\mathrm{N}}\right)\left(\mu \mathrm{g} \mathrm{N} \mathrm{l}^{-1} \mathrm{~d}^{-1}\right)$. Average biomasses $\left(\mu \mathrm{C} \mathrm{Cl}^{-1}\right)$ of the different mesocosms, based on 10 samplings during the $18 \mathrm{~d}$ experiment, are shown for: Craspedophyceae, heterotrophic nanoflagellates (HNF), bacterivorous ciliates (Bact Ciliats), the appendicularian Oikopleura, and total HNP (mean \pm SD)

\begin{tabular}{|cccccr|}
\hline $\mathrm{L}_{\mathrm{N}}$ & $\begin{array}{c}\text { Craspedo- } \\
\text { phyceae }\end{array}$ & HNF & $\begin{array}{c}\text { Bact } \\
\text { Ciliats }\end{array}$ & $\begin{array}{c}\text { Oiko- } \\
\text { pleura }\end{array}$ & \multicolumn{1}{c|}{$\begin{array}{c}\text { Sum } \\
\text { HNP } \pm \mathrm{SD}\end{array}$} \\
\hline 0.00 & 1.3 & 2.5 & 0.3 & 2.0 & $6.1 \pm 4.0$ \\
0.15 & 0.8 & 7.1 & 0.6 & 1.2 & $9.6 \pm 3.2$ \\
0.26 & 1.1 & 6.5 & 0.9 & 0.7 & $9.2 \pm 3.5$ \\
0.44 & 0.8 & 6.4 & 1.2 & 2.4 & $10.8 \pm 3.5$ \\
0.75 & 2.2 & 6.1 & 1.6 & 2.1 & $12.0 \pm 7.7$ \\
1.27 & 1.7 & 7.3 & 1.8 & 0.5 & $11.2 \pm 6.5$ \\
2.16 & 0.8 & 8.4 & 2.0 & 0.4 & $11.5 \pm 7.0$ \\
\hline
\end{tabular}

SD of $11 \pm 6 \%$ and $8 \pm 3 \%$, respectively. For 4 of the mesocosms, time course development in biomass of autotrophs and BAC is presented in Børsheim et al. (2005) and for CIL and COP in Gismervik et al. (2002), whereas contour plots for HNP, CIL and COP are presented in Olsen et al. (2007).

Grazers on BAC (HNP) included 4 dominant plankton groups (Table 4). Except for the zero dose treatment, heterotrophic nanoflagellates (HNF) dominated in terms of biomass, and constituted on average more than $60 \%$ of the grazer biomass. The other 3 groups were similar in terms of biomass (averages 11 to $14 \%$ ). No dose response was observed for Craspedophyceae and Oikopleura. The biomass of HNF in general increased with time, whereas bacterivorous ciliates and Craspedophycea were at their maximum biomass after about $1 \mathrm{wk}$ (data not shown). The highest biomass of Oikopleura was observed at the beginning and towards the end of the experiment.

For the 4 mesocosms with the lowest nutrient loading rate there were no clear trends in DOC as a function of time, but for the 3 highest loading rates DOC accumulated during the second half of the experiment and nearly doubled in the 2 mesocosms with the highest loading rates. Time series for DOC for 4 mesocosms are presented in Børsheim et al. (2005). DON concentration in general decreased slightly with time, but for the mesocosms with the highest nutrient loading rates the lowest concentrations were measured after $\sim 1 \mathrm{wk}$. Within the nutrient loading gradient DOP concentrations changed from decreasing with time to strong accumulation at the highest nutrient loadings (35 to $70 \%$ increase). Average DON and DOP concentrations for each of the mesocosms are presented in Olsen et al. (2011).

\section{Flow network construction}

The first flow network describing the framework for inverse modelling of the food web was with a unidirectional C flow from DOC to BAC. This, however, resulted in solutions without full rank and a clear under- and over-estimation of bacterial production and biomass, respectively. By introducing the BAC $\rightarrow$ DOC flow, we obtained full rank solutions and good correlation between measured and estimated variables. The slope (mean $\pm \mathrm{SD}$ ) for estimated versus measured rates was $0.972 \pm 0.014, r^{2}=0.993$ (Olsen et al. 2007). The BAC $\rightarrow$ DOC flow can be interpreted as excretion or viral induced lysis, and is discussed further below. The uncertainty of the estimated mean $\mathrm{C}, \mathrm{N}$ and $\mathrm{P}$ flows ranged from 0.1 to $7 \%$, with the highest relative uncertainty for small flows (derived from 3000 Monte Carlo simulations for each element; Olsen et al. 2007, 2011).

\section{Estimated bacterial mediated $\mathrm{C}, \mathrm{N}$ and $\mathrm{P}$ flows}

The C uptake by BAC showed evidence of saturation with increasing rates of nutrient loading, and with a total 5-fold variation (Fig. 4). The N uptake was $>99 \%$ DON at the 3 highest loading rates, and averaged $69 \%$ for the 3 lowest. DIN uptake was higher than DON uptake only for the zero loading rate. Thus, with increasing loading rate of DIN to the system the significance of DIN in the total N uptake by BAC decreased. The uptake of both DIP and DOP showed strong saturation tendencies with increasing nutrient loading rates. DIP and DOP uptake were comparable (DIP uptake was $45 \pm 4 \%$ of total, means $\pm \mathrm{SD}$ ). Thus, the balance in the uptake of inorganic and organic $\mathrm{N}$ and $\mathrm{P}$ were completely different within the gradient.

The release of inorganic C (Fig. 4) must be considered differently from that of inorganic $\mathrm{N}$ and $\mathrm{P}$, as DIC release is respiration, which is a resource only for the autotrophs and was present in surplus. Rates of respiration and DOC release by BAC were comparable at the lowest loading rates, but at the 3 highest loadings, DOC release exceeded respiration by approximately one third. Of the $\mathrm{C}$ uptake that was not respired, on average $83 \pm 5 \%$ was released as DOC. For N, releases of DIN and DON were comparable at high loadings (average \%DIN was $47 \%$ ), whereas DON release became more and more important at the 3 lowest loadings (average \%DIN was $23 \%$ ). The release of $\mathrm{P}$ was almost exclusively in the form of DOP, as DIP release was insignificant over the whole loading gradient. 

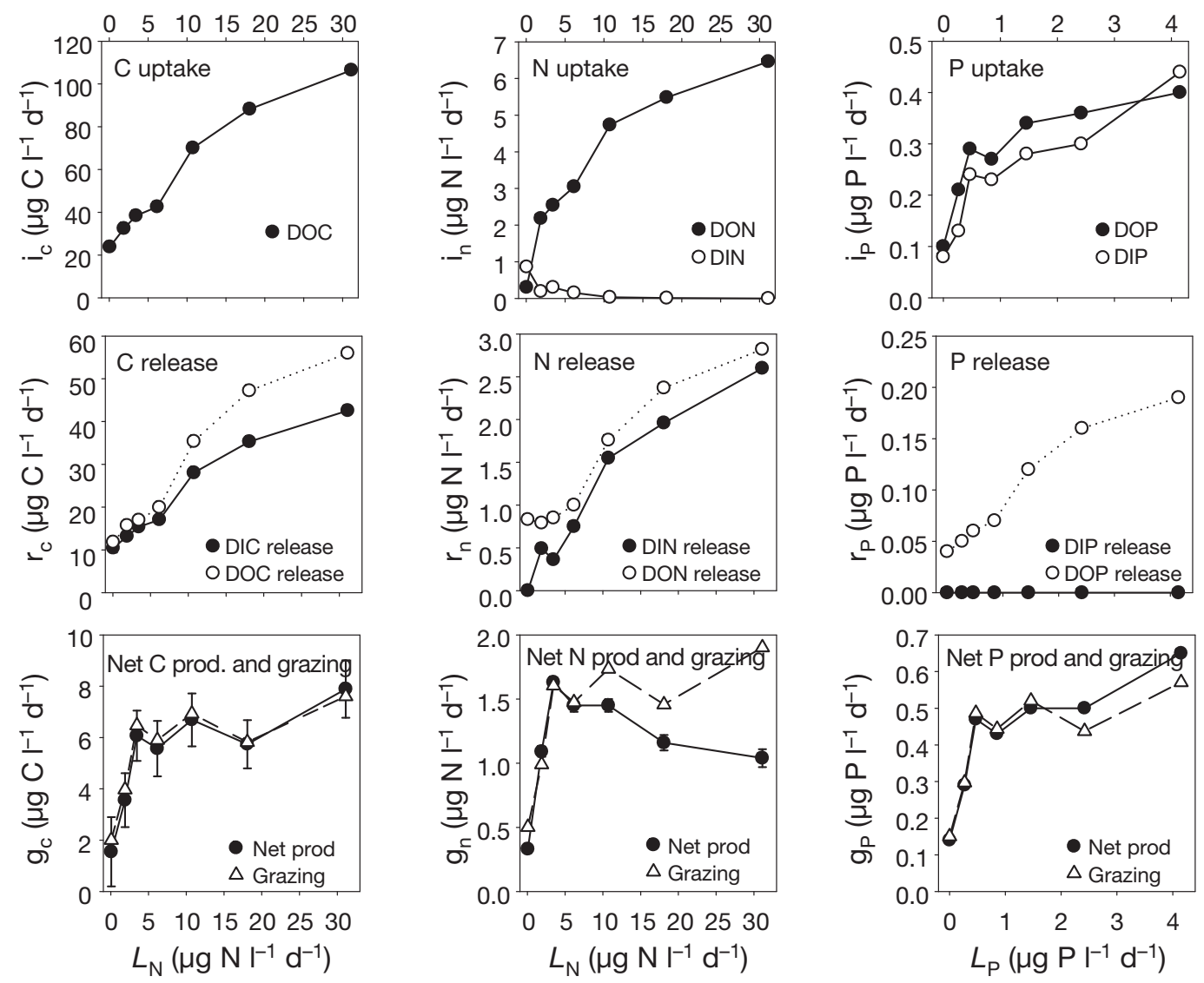

Fig. 4. Results from the flow-network construction for heterotrophic bacteria (BAC), showing uptake, release, and net production (prod) and grazing of $\mathrm{C}, \mathrm{N}$ and $\mathrm{P}$. Values for $\mathrm{C}$ and $\mathrm{N}$ are shown as a function of $\mathrm{N}$ loading rate $\left(L_{\mathrm{N}}\right)$; values for $\mathrm{P}$ are shown as a function of $\mathrm{P}$ loading rate $\left(L_{\mathrm{P}}\right)$

Net bacterial production on a $\mathrm{C}, \mathrm{N}$ and $\mathrm{P}$ basis, i.e. the production that was available for grazers, spanned a factor of 4 to 5 within the loading gradient. The $\mathrm{C}$ response within the gradient was positively correlated to those of $\mathrm{N}$ and $\mathrm{P}$ (Pearson's $\mathrm{r}=0.693$ and 0.699 , respectively). The heterotrophic bacterial production available for grazers and the consumption by grazers was in balance on a $\mathrm{C}$ basis, whereas on an $\mathrm{N}$ and $\mathrm{P}$ basis, some deviations were observed at the highest loading rates (Fig. 4).

The specific uptake of $C$ (normalised to biomass of BAC) showed a weak tendency to saturation with increasing loading (from 1.3 to $2.8 \mathrm{~d}^{-1}$, data not shown). The specific respiration rates increased similarly (from 0.51 to $1.13 \mathrm{~d}^{-1}$ ), whereas the net specific production rate reached saturation at natural loading and was within the 0.08 to $0.22 \mathrm{~d}^{-1}$ range. The lower variation in absolute (Fig. 4) versus specific $\mathrm{C}$ uptake, release and net production rates was due to a 2 -fold increase in the average biomass of BAC within the loading gradient (Fig. 3).

\section{Identification of organisms producing dissolved matter for bacteria}

The production of DOC by autotrophs increased almost linearly with nutrient loading rate (Fig. 5A). Release by heterotrophs showed a weak tendency to saturation, and they were the most significant producers of DOC at all nutrient loading rates. The percent contribution of autotrophs increased linearly with loading rate, from 20 to $43 \%$ within the gradient (Fig. 5B). Even though heterotrophs were the main producers of DOC at all nutrient loading rates (Fig. 5A), the contribution by the 4 groups of heterotrophs varied within the gradient (Fig. 5B). In general, BAC contributed around $45 \%$ of the DOC production in most mesocosms, with a maximum of $66 \%$ in the mesocosm with zero nutrient loading (overall mean $\pm \mathrm{SD}=48 \pm 8 \%$ ). HNP had its highest contribution at low nutrient loading rates $(18 \%)$, decreasing to $<2 \%$ at the higher $(8 \pm 8 \%)$. CIL and COP were comparable in significance, and were most important 


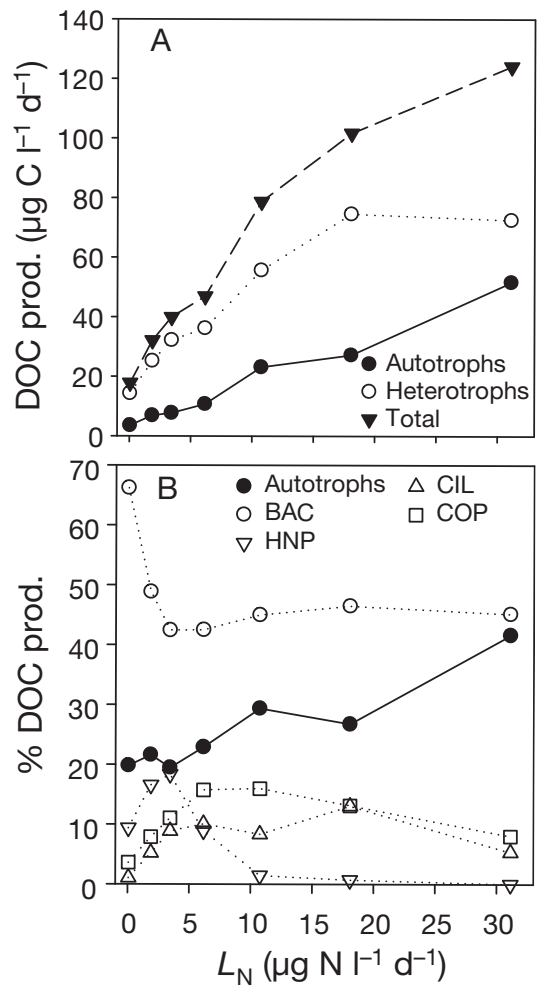

Fig. 5. DOC produced (prod.) by autotrophs and heterotrophs as a function of $\mathrm{N}$ loading rates $\left(L_{\mathrm{N}}\right)$. A: Production by autotrophs and heterotrophs and the sum in absolute rates. B: Percent contribution of autotrophs and the 4 functional heterotrophic groups. See Table 2 for an explanation of functional group abbreviations

at moderate nutrient loading rates $(7 \pm 4 \%$ and $11 \pm$ $4 \%$, respectively). A ranking of the average contribution of heterotrophs to the production of DOC is: BAC $>$ COP $=$ HNP $=$ CIL .

For the production of dissolved $\mathrm{N}$ and $\mathrm{P}$, the picture was more complex as both inorganic and organic forms are resources for heterotrophic bacteria, and the dominance of the heterotrophs is even stronger than for $\mathrm{C}$ as a priori (Fig. 1) the autotrophs did not release inorganic $\mathrm{N}$ and $\mathrm{P}$ (Fig. 6A,D). For autotrophs, the release of DON and DOP increased linearly with nutrient loading rate (Fig. 6A,D), amounting to 19 to $41 \%$ of the total DON produced and 10 to $36 \%$ of the total DOP produced (Fig. 6B,E). The average contribution of autotrophs to the production of DON and DOP was $26 \pm 7 \%$ and $21 \pm 8 \%$, respectively.

The relative significance of the 4 heterotrophic groups to DON and DOP production showed similarities to DOC production. In general, the contribution by BAC was high, and was highest at the zero nutrient loading rate, amounting overall to $45 \pm 5 \%$ of total DON and $30 \pm 9 \%$ of total DOP produced. The importance of HNP was high at low to moderate nutrient loading (average $21 \%$ of DON and $38 \%$ of DOP), decreasing to $<5 \%$ at higher loading rates. The overall averages were $11 \pm 10 \%$ of DON and 23 $\pm 19 \%$ of DOP produced. Both CIL and COP were more significant producers of dissolved organic nutrients at moderate to high nutrient loadings, where typical CIL and COP releases amounted to 9 and $14 \%$ of total DON and 11 and $28 \%$ of total DOP produced, respectively. The average release for CIL and COP, respectively, was $7 \pm 3 \%$ and $12 \pm 4 \%$ of DON, and $8 \pm 6 \%$ and $19 \pm 12 \%$ of DOP produced. Thus a ranking of the average contribution of heterotrophs to the production of DON is: $\mathrm{BAC}>>\mathrm{COP}=\mathrm{HNP}>$ CIL, and for DOP: BAC > HNP > COP > CIL.

For the production of inorganic N and $\mathrm{P}$, the HNP group had the most significant role (Fig. 6C,F). Its contribution at low and moderate nutrient loading rates was $>50 \%$ of total DIN and $>70 \%$ of total DIP produced, and with $37 \pm 16 \%$ and $66 \pm 14 \%$, respectively. The contribution by BAC to DIN production was moderate ( $12 \pm 6 \%$ of total) and zero for DIP. Both the CIL and the COP groups made moderate contributions, and in contrast to the HNP, their significance increased at the higher nutrient loading rates. Overall contributions were $20 \pm 8 \%$ of total DIN and $8 \pm 7 \%$ of total DIP produced for CIL, and $31 \pm 4 \%$ of total DIN and $26 \pm 7 \%$ of total DIP produced for COP. The ranking of the average contribution of heterotrophs to the total release of DIN is: $\mathrm{HNP}=\mathrm{COP}>\mathrm{CIL}>\mathrm{BAC}$, and for DIP: HNP >> COP >> CIL >> BAC.

\section{DOC production and utilisation as a function of autotrophic production}

The total production and consumption of DOC as a function of net autotrophic production (total $\mathrm{CO}_{2}$ fixation minus autotrophic respiration) increased linearly with nutrient loading rate, but with a tendency for saturation at an autotrophic production $>200 \mu \mathrm{g}$ $\mathrm{C}^{-1} \mathrm{~d}^{-1}$ (Fig 7A). For DOC production, the slope of the relationship was 0.419 (dimensionless) with an intercept of $22.4 \mu \mathrm{g} \mathrm{Cl}^{-1} \mathrm{~d}^{-1}\left(\mathrm{R}^{2}=0.974\right)$, and for DOC consumption, the slope and intercept of the relationship were 0.333 (dimensionless) and $25.0 \mu \mathrm{g} \mathrm{Cl}^{-1} \mathrm{~d}^{-1}$, respectively $\left(R^{2}=0.975\right)$. The production of DOC was higher than consumption at a net autotrophic production of $>50$ to $100 \mu \mathrm{g} \mathrm{Cl}^{-1} \mathrm{~d}^{-1}$. This occurred at an autotrophic production comparable to, or slightly higher than the level in the mesocosm with natural loading (see methods), and resulted in an accumulation of DOC (see below). A consequence of the posi- 


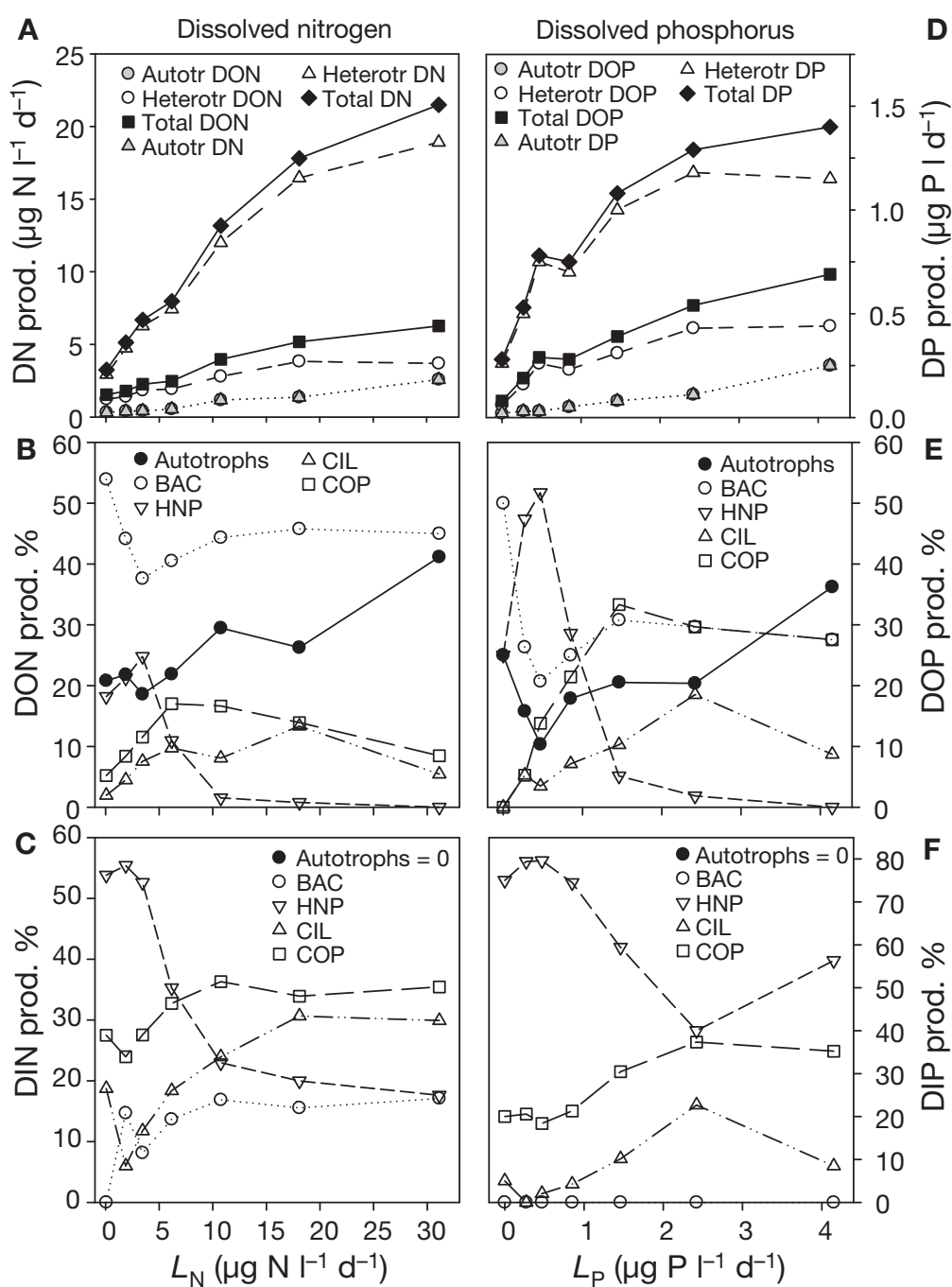

Fig. 6. Production (prod) of dissolved $\mathrm{N}$ and $\mathrm{P}$ by autotroph and heterotrophs as a function of $\mathrm{N}\left(L_{\mathrm{N}}\right)$ and $\mathrm{P}\left(L_{\mathrm{P}}\right)$ loading rates, respectively. DN, DP: dissolved total, DON, DOP: dissolved organic, DIN, DIP: dissolved inorganic $\mathrm{N}$ and $\mathrm{P}$, respectively. A: Production of DN and DON by autotrophs and heterotrophs and the sum in absolute rates. Percent contribution by autotrophs and heterotrophic functional groups to total production of (B) DON and (C) DIN. D: Production of DP and DOP by autotrophs and heterotrophs and the sum in absolute rates. Percent contribution by autotrophs and heterotrophic functional groups to total production of (E) DOP and (F) DIP. See Table 2 for an explanation of functional group abbreviations

\section{Fate of DOC uptake and importance for copepods}

The fate of the DOC consumed by BAC varied only slightly within the primary production gradient (Fig. 7C). The percentage of the consumption respired or ending up as DOC again varied little (means \pm SD were $41 \pm 1 \%$ and $49 \pm 3 \%$, respectively). It must be noted that DOC production is averaged for the $18 \mathrm{~d}$ of the study, and that there was a considerable lag time between consumption and fate (see 'Discussion'). A low fraction of the BAC production was available for grazers (average $10 \pm 4 \%$ ), but it varied by almost a factor of 3 and was highest at a net autotrophic production typical for moderate, close to natural, nutrient loading rates $\left(50 \mu \mathrm{g} \mathrm{Cl}^{-1} \mathrm{~d}^{-1}\right)$.

The contribution of BAC to the flow of carbon up the food web can be illustrated by calculating the percent indirect contribution to the total ingestion by COP. In our flow network, there are 2 possible routes involving 1 or 2 trophic transfers before ingestion by COP (Fig. 1). When the net autotrophic production was low $\left(<40 \mu \mathrm{g} \mathrm{C} \mathrm{l}^{-1} \mathrm{~d}^{-1}\right)$, the contribution of BAC carbon to the total ingestion by $\mathrm{COP}$ was $5.5 \%$, but decreased inversely with autotrophic production above this threshold and was $<0.5 \%$ at an autotrophic production $>120 \mathrm{\mu g} \mathrm{C} \mathrm{l}^{-1} \mathrm{~d}^{-1}$ (Fig. 8). On average, C originating from $\mathrm{BAC}$ was $2.34 \pm 2.26 \%$ of the $\mathrm{C}$ ingested by COP. Counter intuitively, the 'longer route' via CIL contributed three-quarters of the $\mathrm{C}$ with BAC origin ingested by COP (Fig. 8), at all levels of autotrophic production except $>300 \mu \mathrm{C} \mathrm{Cl}^{-1} \mathrm{~d}^{-1}$.

\section{Growth efficiency of $\mathbf{C}, \mathbf{N}$ and $\mathbf{P}$}

consumption of DOC as a percentage of net autotrophic production decreased hyperbolically from 240 to $40 \%$ and from 320 to $34 \%$, respectively (Fig. 7B), and with a DOC production and BAC consumption of $91 \pm 69 \%$ and $99 \pm 101 \%$ of the autotrophic production (means $\pm \mathrm{SD}$ ), respectively. The uptake of DOC by BAC as a percent of DOC produced varied considerably less (range 86 to $133 \%, 98$ $\pm 17 \%$; Fig. 7B).
GE may be defined as the percentage of a resource taken up which is converted into biomass. Thus, excretion of a resource will entail reduced GE, whereas mortality does not influence GE. This complicates estimates of GE in the present study, as the flux from heterotrophic bacteria to DOC may be due to excretion or to virus-induced mortality and lysis. We have 

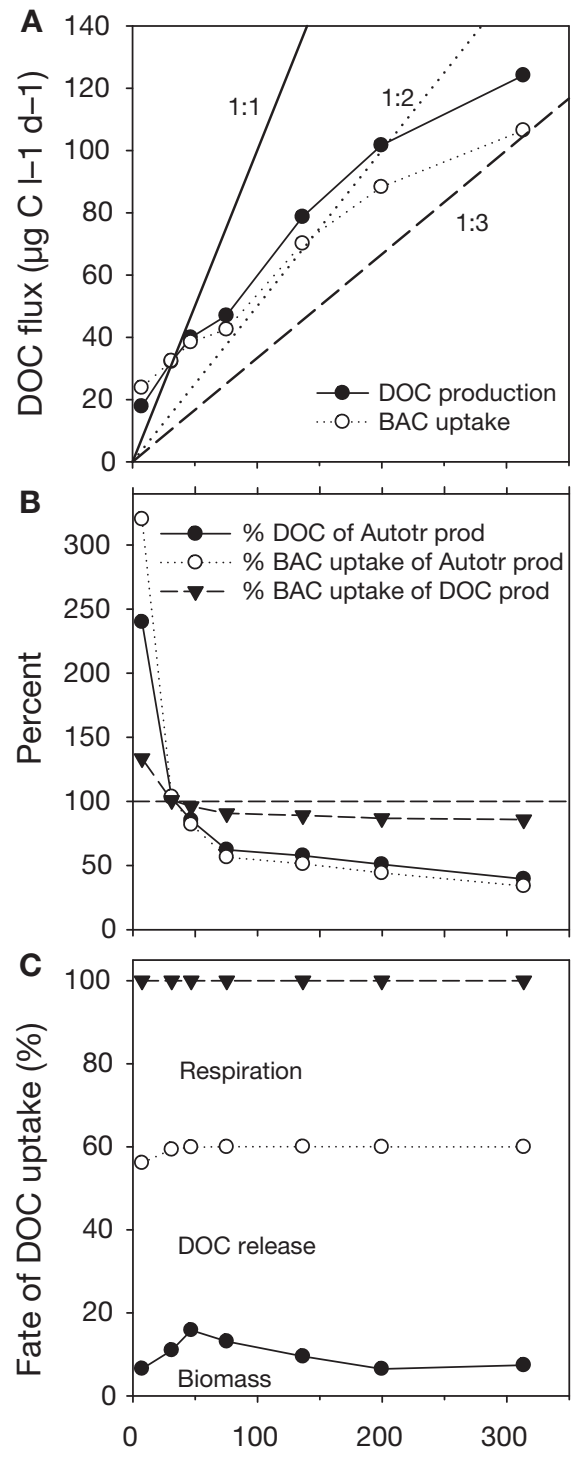

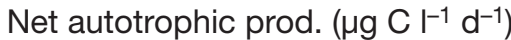

Fig. 7. Production (prod) of DOC and uptake by heterotrophic bacteria (BAC) as a function of net autotrophic production (Autotr prod) (gross $\mathrm{C}$ fixation minus autotrophic respiration). A: Absolute rates. Straight lines indicate when DOC flux is equal to $(1: 1), 50 \%(1: 2)$ or $33 \%(1: 3)$ of net autotrophic production. B: Percent production and utilisation of DOC. Horizontal line $=100 \%$. C: Fate of DOC taken up by heterotrophic bacteria. DOC release from BAC can be interpreted as excretion or due to viral lysis

accordingly calculated minimum and maximum estimates assuming, respectively, that all DOC released was either by excretion or as a result of viral lysis. As a minor fraction of cellular $\mathrm{N}$ and $\mathrm{P}$ is inorganic (Vadstein 2000), the same assumptions may be applied for $\mathrm{N}$ and $\mathrm{P}$ release. Considerable variation was observed in GE between $\mathrm{C}, \mathrm{N}$ and $\mathrm{P}$ (hereafter $\mathrm{GE}_{\mathrm{C}}$, $\mathrm{GE}_{\mathrm{N}}$ and $\mathrm{GE}_{\mathrm{P}}$ respectively), and at least for $\mathrm{GE}_{\mathrm{N}}$ the

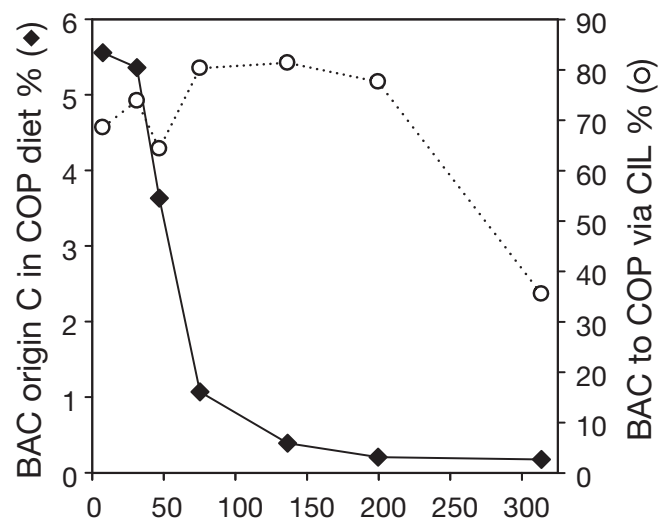

Net autotrophic production $\left(\mu \mathrm{C} \mathrm{Cl}^{-1} \mathrm{~d}^{-1}\right)$

Fig. 8. The contribution of heterotrophic bacteria (BAC) to the carbon flow up the food web as a function of net autotrophic production (gross $\mathrm{C}$ fixation minus autotrophic respiration). : significance of $\mathrm{C}$ of $\mathrm{BAC}$ origin to the total ingestion of copepods (COP); O: percent of this $\mathrm{C}$ going through the 'long' route via heterotrophic ciliates (CIL)

variation was a function of the nutrient loading rate (Fig. 9). Overall minimum and maximum $\mathrm{GE}_{\mathrm{C}}$ estimates (means $\pm \mathrm{SD}$ ) were $10 \pm 3 \%$ and $51 \pm 3 \%$, respectively, and these were highest for the nutrient loading rate that was comparable to the natural (16 and $56 \%$, respectively). Estimated $\mathrm{GE}_{\mathrm{N}}$ was much higher and more variable, with minimum and maximum averages of $35 \pm 14 \%$ and $76 \pm 13 \%$, respectively, and with lower $\mathrm{GE}_{\mathrm{N}}$ at higher loadings. The highest minimum and maximum estimates for $\mathrm{GE}_{\mathrm{N}}$ were 57 and $100 \%$, respectively. $\mathrm{GE}_{\mathrm{P}}$ was even higher, with average minimum and maximum estimates of $82 \pm 5 \%$ and $100 \pm 0 \%$, respectively. As BAC released no DIP, the estimated maximum GE $_{P}$ was $100 \%$ at all loadings. The minimum estimates of GE were highly correlated, with $\mathrm{R}^{2}=0.942$ and $\mathrm{R}^{2}=$ 0.859 for $G_{P}$ versus $G_{C}$ and $G_{N}$ versus $G_{C}$, respectively.

\section{Importance of inorganic nutrients, competition with autotrophs and re-mineralisation}

The percent inorganic nutrient uptake of total $\mathrm{N}$ and $\mathrm{P}$ taken up by BAC was quite different (Fig. 10A). Whereas DIP varied only between 38 and $52 \%$ of total P uptake (average $45 \pm 4 \%$ ), the range for DIN was 74 to $0 \%$ (average $14 \pm 25 \%$ ). Thus, inorganic $\mathrm{P}$ was 3 times more significant than inorganic $\mathrm{N}$ in the total uptake of $\mathrm{P}$ and $\mathrm{N}$ by BAC, and the variability was 6 times less. The strength of the competition between BAC and autotrophs can be expressed 


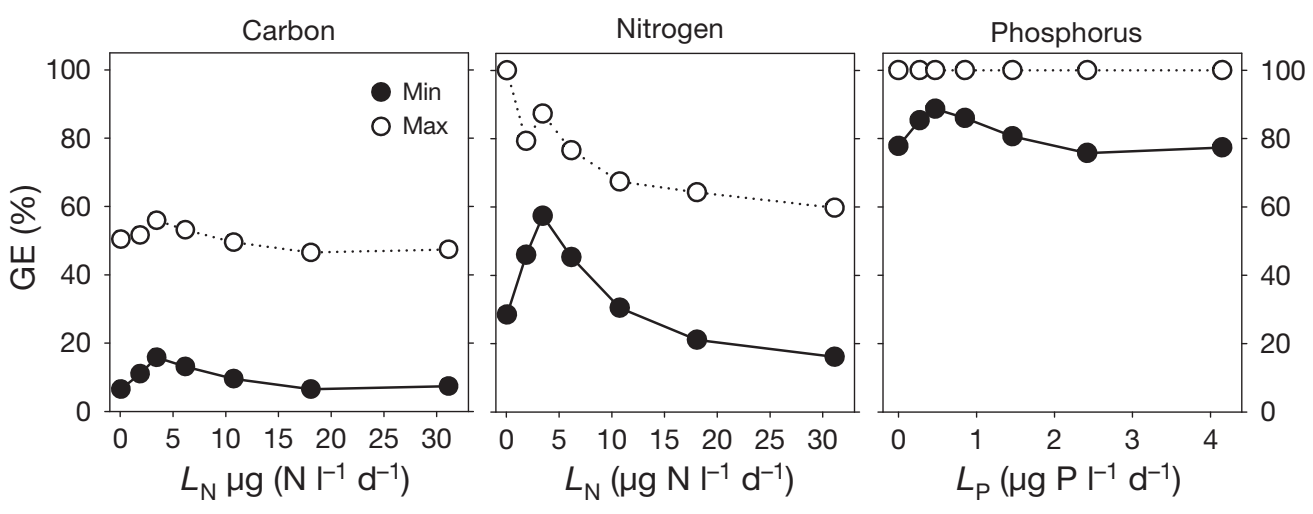

Fig. 9. Growth efficiency (GE) in utilisation of $\mathrm{C}, \mathrm{N}$ and $\mathrm{P}$ taken up by heterotrophic bacteria (BAC) as a function of $\mathrm{N}$ and $\mathrm{P}$ loading rates ( $L_{\mathrm{N}}$ and $L_{\mathrm{P}}$, respectively). Minimum and maximum estimates assume DOC release (Fig. $7 \mathrm{C}$ ) to be wholly excretion or wholly due to viral lysis, respectively

as the percent contribution of BAC in the total uptake of inorganic nutrients by BAC and autotrophs. For both DIN and DIP, the uptake by BAC was around one third of the total uptake at zero loading, decreasing to 0 and $8 \%$, respectively, at the highest rates of nutrient loading (Fig. 10A). On average, the contribution of BAC to the total uptake of inorganic $\mathrm{N}$ and P was $6 \pm 11 \%$ and $18 \pm 9 \%$, respectively. Thus BAC were more significant competitors with autotrophs for DIP, as on average the DIP uptake was 3-fold higher than that of DIN and was always $>8 \%$ of the total uptake.

The role of BAC as re-mineralisers of $\mathrm{N}$ and $\mathrm{P}$, reflected by their net release of DIN and DIP as a percentage of consumed DON and DOP, was calculated from the data. Excluding the mesocosm where nutrients were not added (with $74 \%$ DIN uptake), BAC were net re-mineralisers of $\mathrm{N}$, with a net release of DIN (release minus uptake) which was $24 \pm 13 \%$ of consumed DON (Fig. 10B). In contrast BAC were net consumers of DIP at all loadings and accordingly did not re-mineralise this nutrient. For every 100 molecules of P taken up as DOP, they had on average to consume 84 DIP molecules to cover their requirements (net release of $-84 \pm 13 \%$ ). For both $\mathrm{N}$ and $\mathrm{P}$ it seemed that the percent uptake of inorganic nutrient of the total had to be below 15 to $25 \%$ for BAC to act as re-mineralisers (Fig. 10B).

\section{DOM accumulation and turnover time}

Both DOC and DOP accumulated at the higher nutrient loading rates, whereas DON was consumed at a specific rate of $0.3 \pm 0.2 \% \mathrm{~d}^{-1}$ (negative accumulation) when excluding the mesocosm without the addition of nutrients (Fig. 11A). At the higher nutri- ent loading rates, DOP accumulated more rapidly than DOC. The change to positive accumulation occurred at low nutrient loading rates for both DOP
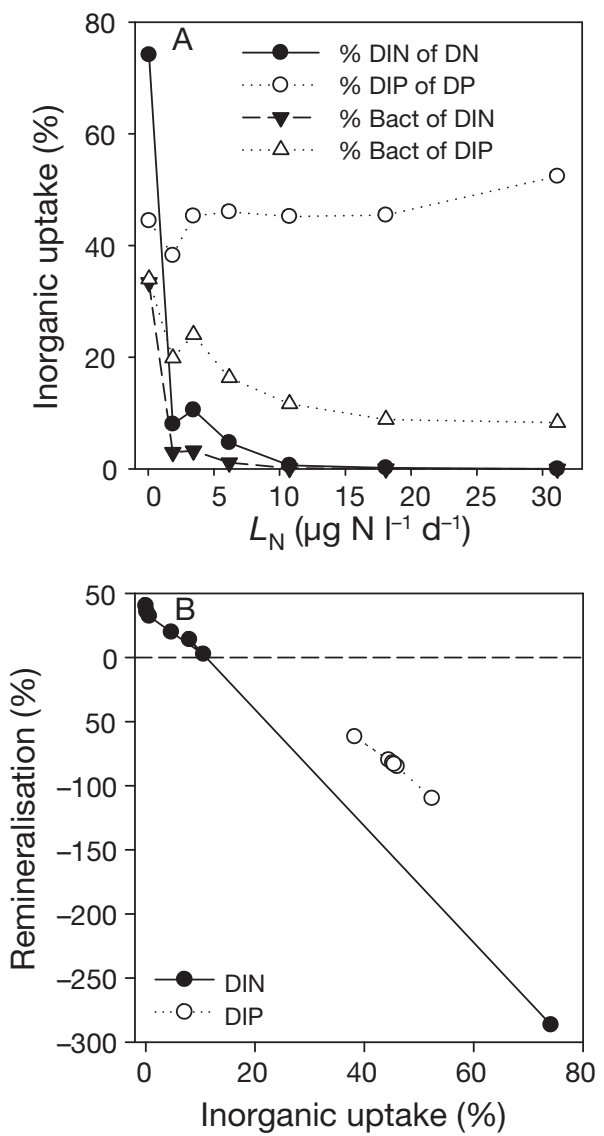

Fig. 10. (A) Percent contribution of DIN and DIP uptake by heterotrophic bacteria (BAC) to the total uptake of inorganic nutrients by BAC plus autotrophs (\%BAC of DIX) and to total DN and DP uptake by BAC (\%DIX of DX) as a function of $N$ loading rate $\left(L_{N}\right)$. (B) Percent re-mineralisation of $N$ and $\mathrm{P}$ as a function of percent inorganic uptake by BAC 

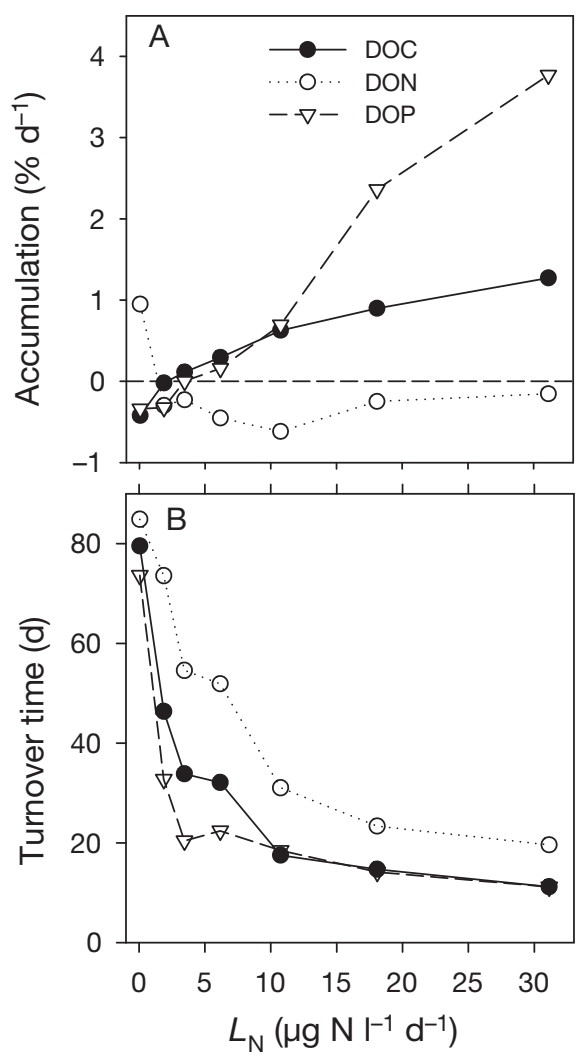

Fig.11. (A) Accumulation and (B) turnover time of DOC, DON and DOP as a function of $\mathrm{N}$ loading rate $\left(L_{\mathrm{N}}\right)$. Turnover time was based on averages in dissolved nutrients produced and measured concentrations

and DOC. The same pattern was also evident for the absolute accumulation rates and for measured changes in the concentration of DOC, DON and DOP (data not shown, but see Børsheim et al. 2005 for DOC). The turnover time of dissolved organic $\mathrm{C}, \mathrm{N}$ and $\mathrm{P}$ decreased by a factor of 7.1, 4.3 and 6.6 , respectively, with increasing nutrient loading rate (Fig. 11B). In general, the turnover times of DOC and DOP were similar, whereas the turnover times of DON were considerably longer at the medium to high nutrient loading rates.

\section{Trophic position of bacteria}

The trophic position of BAC was calculated on a C, N- and P-basis (Fig. 12). BAC relies solely on DOC for $\mathrm{C}$, whereas for $\mathrm{N}$ and $\mathrm{P}$, the resource can be a mixture of inorganic (trophic position zero) and organic matter (trophic position dependent on the source). In general, the trophic position of BAC peaked at a low nutrient loading, but the variation as

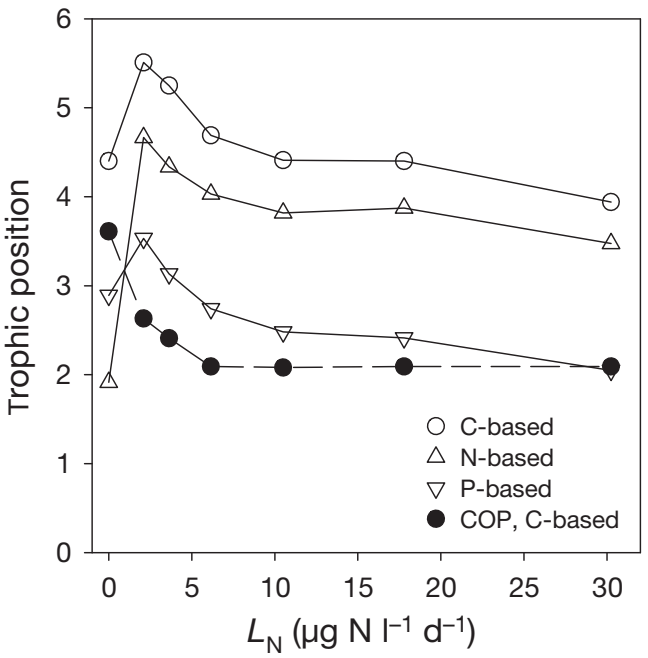

Fig. 12. Estimated trophic position of heterotrophic bacteria as function of $\mathrm{N}$ loading rate $\left(L_{N}\right)$. Trophic position was calculated on a $\mathrm{C}-, \mathrm{N}$ - and $\mathrm{P}$ - basis, and trophic position on the

$\mathrm{C}$-basis of copepods (COP) is included for comparison

a function of the nutrient loading rate was low. The differences in trophic position on a C-, $\mathrm{N}$ - and P-basis were more striking than the dependence of loading rate, and values averaged $4.7 \pm 0.5,3.7 \pm 0.8$ and $2.7 \pm 0.5$, respectively $( \pm \mathrm{SD})$. They were all significantly different $(\mathrm{p}<0.05)$. Interestingly, on a C-basis, BAC are at the top of the food web we studied, as their trophic position was 2 times higher than that for COP $(2.4 \pm 0.5)$. The trophic position of COP was significantly lower than the $\mathrm{C}$ - and N-based average values of BAC $(p<0.005)$, but not different from the P-based estimate $(p=0.32)$.

\section{DISCUSSION}

\section{Methodological aspects}

The methodological aspects of the inverse solutions of the flow networks for $\mathrm{C}, \mathrm{N}$ and $\mathrm{P}$ of this study have already been thoroughly discussed and the results seem to be robust (Olsen et al. 2006, 2007, 2011). The accuracy of the estimated rates was higher than those for conventional methods, and was in good agreement with the measured data. The fact that we had to include the BAC-to-DOC flow to obtain full rank solutions and agreement with measured variables is an example of the strength of inverse modelling compared to traditional budget calculations. The same is indicated by the fact that we obtained variable growth yields dependent on the nutrient loading rate. In a similar experiment conducted in the Baltic 
Sea (Olsen et al. 2006), we also had to include the BAC-to-DOC flow to obtain full rank solutions, which again points to the robustness of the method. The BAC-to-DOC flow can be interpreted as a mixture of excretion which is known to occur under excess $\mathrm{C}$ conditions (Kawasaki \& Benner 2006, Madigan et al. 2009) and virus-induced mortality which operationally results in the production of dissolved organic matter (Weinbauer 2004), and is discussed further below. Future studies should investigate the implications of using thymidine-based production measurement in systems where viral-induced mortality seem to dominate, and to what extent the thymidine method measures phage production. In conclusion, range-constrained inverse modelling as done in the present experiment seems to be less influenced by the 'delusions' of the investigator and are therefore likely less biased and less investigator-dependent.

In the subsequent discussion, it is important to remember that the rates presented are averages for the entire $18 \mathrm{~d}$ period of the experiment. Thus, the time dynamics which occurred (e.g. Fig. 2) were lost, and the correlations between rates should be interpreted with caution as they do not cover the time resolution of these processes (see Lønborg et al. 2009). However, the use of averages for the whole experimental period results in more conservative conclusions and they should therefore be more robust.

\section{Which organisms supply DOC and organic and inorganic $\mathrm{N}$ and $\mathrm{P}$ resources that heterotrophic bacteria rely on for growth?}

Traditionally, it has been assumed that autotrophs (phytoplankton) are the main producers of DOC (Dafner \& Wagersky 2002), but except for at extreme nutrient loading rates, their contribution was only 20 to $30 \%$ in the present study. Thus, heterotrophs were the main contributors, with heterotrophic bacteria as the clear number one contributor accounting for approximately $50 \%$ of the total. This makes heterotrophic bacteria a spinning wheel for consuming and producing DOC, even though it may be argued that viral lysis is not a host-driven process. Their huge impact was mainly due to a short turnover time and not high biomass. Some studies indicating that a large share of DOC in marine systems is of bacterial origin (McCarthy et al. 1998, Ogawa et al. 2001, Lønborg et al. 2009) provide support to our findings. However, the above and similar studies investigated bulk characteristics of DOC and the net rate of change, and our study is likely the first to present absolute rates. Whereas the production of DOC by protozoans is little studied (Sherr et al. 1982), several studies point to metazoans as important producers of DOC (Olsen et al. 1986, Strom et al. 1997, Olsen et al. 2002). However, few studies have estimated complete budgets of DOC production, even though some have pointed out the importance of heterotrophs relative to autotrophs (e.g. Vadstein et al. 1993).

The pattern in production of DON and DOP showed similarities with DOC production. This is interesting, as it has been assumed that phytoplankton produce mainly carbon-rich compounds (e.g. Granum et al. 2002, Børsheim et al. 2005). The almost complete dominance of protozoa in the production of DIN (mean $57 \%$ ), and in particular of DIP (mean $74 \%$ ), is striking, and implies that heterotrophic bacteria are insignificant re-mineralisers (see below). The fact that protozoa and not heterotrophic bacteria account for the bulk of re-mineralisation was previously stated by Johannes (1968) and re-stated regarding P by Vadstein et al. (1993). So far, it has not been generally accepted, even though mechanistic explanations exist (Vadstein 2000).

\section{How large a share of primary production ends up as DOC and how much of this is taken up by heterotrophic bacteria?}

It has generally been considered that 10 to $50 \%$ of autotrophic production ends up as DOC that is available for heterotrophic bacteria (e.g. Azam et al. 1983). However, in the present study, the amount of DOC relative to primary production was close to this range (40 to $58 \%$ ) only at high nutrient loadings, whereas at low to moderate loadings, DOC production was relatively greater and comparable to primary production (85 to $240 \%$ ). The divergence between our results and those previously published (e.g. Conan et al. 2007, Lønborg et al. 2009) may be due to the fact that we quantified gross production of DOM whereas others quantified net production (production minus consumption). The high proportion of autotrophic production ending up as DOC is due to 2 factors: (1) all organisms released a considerable fraction of consumed or fixed C as DOC, and (2) there is recycling of DOC within the food web because organic $\mathrm{C}$ leaves the food web only by respiration and export. DOC may, for example, be released by phytoplankton, consumed by bacteria, egested by grazers and consumed by bacteria again. This second point (recycling) was given some attention in the late 1980s. It was claimed that DOC available to het- 
erotrophic bacteria was dependent on the food web structure and GE, and may reach $>100 \%$ of autotrophic production on a seasonal basis (Strayer 1988, Vadstein et al. 1989). This phenomenon has not been much studied since then, and does not seem to have taken root in mainstream thinking.

\section{What is the fate of the DOC taken up by bacteria and of the heterotrophic bacterial biomass, and to what extent do heterotrophic bacteria contribute to the $\mathrm{C}$ flow up the planktonic food web?}

A large number of studies have stated that the microbial loop may contribute to production at higher trophic levels, which is not strange taking into consideration the high proportion of autotrophic production which heterotrophic bacteria consume (in this study 34 to $320 \%$ ). However, their role will depend on how efficiently consumed DOC is converted to biomass and on the number of trophic transfers required to reach (for example) copepods. In the present study, only 7 to $16 \%$ (average $10 \%$ ) of the DOC consumed was available for phagotrophs, which translates to 3 to $12 \%$ of the autotrophic production. Excretion or viral lysis and respiration were of comparable importance in reducing the fraction of DOC consumption by heterotrophic bacteria available for predators. In contrast to most other studies where viral lysis and predation are considered to cause comparable loss rates (see Weinbauer 2004), our study suggests that the sum of viral lysis and excretion was between 74 and $89 \%$ of the C loss by heterotrophic bacteria (average $83 \%$ ). This provides indirect support for the hypothesis that viruses and not resource competition are the main factor structuring community composition (Thingstad 2000, Vadstein 2011).

As far as we know, the study by De Laender et al. (2010) is the only other example in the literature that addresses the significance of heterotrophic bacterial production for ingestion by marine copepods. They concluded that during spring and summer, 20 to $80 \%$ and 80 to $90 \%$, respectively, of the copepod diet was protozoa. This far exceeds our estimates, even though in our study a considerably higher fraction of autotrophic production ended up as DOC. The discrepancy may be due to the fact that De Laender et al. (2010) based their study on literature values from a variety of sources and allowed all DOC produced to be consumed by heterotrophic bacteria. The latter procedure is not in accordance with observations (Thingstad et al. 1997), nor the fact that heterotrophic bacteria may be limited by mineral nutrients (Vad- stein 2000, 2011, Olsen et al. 2011). Although the average contribution of heterotrophic bacterial production to the diet of copepods was low (2\%) in our study, it is interesting to note that it varied 10-fold and may thus be critical under oligotrophic or summer situations. This is in accordance with the findings of De Laender et al. (2010). Bacterial biomass requires between 2 and 3 trophic transfers to reach copepods, and the counterintuitive result of our study was that the longer path contributed three-quarters of the total bacterial production to copepods.

As both respiration by heterotrophic bacteria (Robinson 2008) and rates of viral induced lysis (Breibart et al. 2008) are generally accepted to be high, our findings on the fate of consumed DOC may reveal a general pattern in marine systems. This is supported by tracer experiments in mesocosms (Ducklow et al. 1986). Limnetic systems where daphnids dominate the metazoan zooplankton may be different, as daphnids are efficient grazers of heterotrophic bacteria (Børsheim \& Olsen 1984, Vadstein et al. 1993).

\section{How efficiently do heterotrophic bacteria utilise $\mathrm{C}$, $\mathbf{N}$ and $\mathbf{P}$ taken up for the production of new biomass?}

The differences in GE for the different elements reflect differences in their role in metabolism, the chemical form of the element (e.g. DON versus DIN), and the balance between the elements taken up in comparison to the demands. Uptake of $\mathrm{C}, \mathrm{N}$ and $\mathrm{P}$ can be linked when the resource is organic, but uncoupled when $\mathrm{N}$ and $\mathrm{P}$ uptake is inorganic and when $\mathrm{C}$ uptake is carbohydrates and lipids (excluding phospholipids). The link between $\mathrm{C}$ and $\mathrm{P}$ uptake, unlike that between $\mathrm{C}$ and $\mathrm{N}$, is weak as in general $\mathrm{P}$ is taken up as $\mathrm{PO}_{4}{ }^{3-}$ after extracellular hydrolysis (Vadstein 2000, Madigan et al. 2009). One could hypothesise that $\mathrm{GE}_{\mathrm{C}}$ will be lower than $\mathrm{GE}_{\mathrm{N}}$ especially $\mathrm{GE}_{\mathrm{P}}$, as $\mathrm{C}$ is strongly linked to the generation of energy whereas $\mathrm{P}$ is loosely linked. This was in fact what we observed for both the maximum and minimum GE estimates. Also, the differences in the loading dependence of GE for $\mathrm{C}, \mathrm{N}$ and $\mathrm{P}$ were striking, with higher dependence for $\mathrm{N}$ and $\mathrm{C}$ than for $\mathrm{P}$. This suggests that the utilisation of $\mathrm{N}$ resources are more dynamic, and that in eutrophic systems heterotrophic bacteria fulfil their $\mathrm{N}$ requirements through uptake of organic matter (Thingstad \& Lignell 1997), and further that $\mathrm{P}$ is an element always in strong demand (Vadstein 2000). 
The $\mathrm{GE}_{\mathrm{C}}$ values obtained indicate that the quality of the DOM changed at high productivity in a way which reduced its quality on a C-basis. As a consequence, $\mathrm{GE}_{\mathrm{N}}$ also went down, as less of the $\mathrm{N}$ content in DOM was required for biomass production. This observation could be related to the doubling in the contribution of autotrophs to DOC and DON production at high nutrient loading, which increased from 20 to $40 \%$. Moreover, it suggests that for nutrient loading with a relatively balanced $\mathrm{N}$ :P ratio, extracellular production by phytoplankton is not dominated by N-poor substrates like polysaccharides, as proposed by several authors (e.g. Biddanda \& Benner 1997, Granum et al. 2002).

The value of $\mathrm{GE}_{\mathrm{C}}$ varied considerably, and our maximum and minimum estimates almost spanned the range given in the literature. The fact that most recent $\mathrm{GE}_{\mathrm{C}}$ values published for natural bacterioplankton (del Giorgio \& Cole 2000, Smith \& Prairie 2004) are between our maximum and minimum estimates based on the extreme assumptions that all DOC is produced by excretion or lysis due to viruses, respectively, may suggest that both virus-induced lysis and excretion were involved in the flux of $\mathrm{C}$ from bacteria to the DOC pool. This is supported by the fact that heterotrophic bacteria were most likely P-limited (Olsen et al. 2011), as the excretion of DOC is mainly a C-surplus phenomenon (Kawasaki \& Benner 2006, Madigan et al. 2009). So far, little attention has been given to active excretion of DOC by heterotrophic bacteria in natural systems, which is likely a consequence of the old carbon/energy limitation paradigm. However, it has been shown recently that heterotrophic bacteria may excrete 14 to $31 \%$ of the C taken up during active growth (Kawasaki \& Benner 2006), and bacteria produce a variety of compounds with variable bioavailability (Ogawa et al. 2001, Lønborg et al. 2009).

\section{To what extent do heterotrophic bacteria utilise inorganic versus organic $\mathbf{N}$ and $P$ resources, and are they net re-mineralisers of $\mathbf{N}$ and $P$ ?}

For heterotrophic bacteria, DIP was approximately half of the P uptake throughout the nutrient loading gradient, whereas the significance of DIN as an $\mathrm{N}$ source decreased rapidly from three-quarters to zero with increasing loading rate. This reflects the difference between organic $\mathrm{N}$ and $\mathrm{P}$ resources; whereas $\mathrm{P}$ is bound as phosphate esterified to organic constituents and has to be hydrolysed before uptake (Vadstein 2000, Madigan et al. 2009), N is bound in constituents like amino acids and nucleotides that can be assimilated directly (Church 2008, Madigan et al. 2009). A consequence of this is a larger niche overlap between autotrophs and heterotrophic bacteria for $\mathrm{P}$ than for $\mathrm{N}$, and accordingly a stronger competition for DIP than for DIN. This difference in competition is also reflected by the fact that, on average, the percent uptake of the total by heterotrophic bacteria was 3 times higher for DIP than for DIN. Tracer studies with radioactive phosphate have shown that the fraction taken up by bacteria is typically 60 to $90 \%$ (see Vadstein 2000), which is 3 to 10 times higher than the percent contribution reported in the present study. It must be noted that the uptake of DIN and DIP presented here is the net uptake, and the above discrepancy gives support to the existence of a bidirectional flux between DIN and DIP, and osmotrophs. This process is thought to be significant in the competition for P (Lean \& Nalewajko 1976, Olsen 1989, Vadstein 2000), and is verified in physiological (Olsen 1989, Vadstein 1998) and competition studies (Olsen et al. 1989), but its ecological implications have received little attention.

The difference in the significance of heterotrophic bacteria in the re-mineralisation of $\mathrm{N}$ and $\mathrm{P}$ was striking, with a role as net consumers of DIP and as net remineralisers of $\mathrm{N}$ under all conditions except for the mesocosm with a severely nutrient starved community (zero nutrient loading). For $\mathrm{P}$, this is in accordance with mass balance considerations (Vadstein et al. 1993, Vadstein 2000), and the more complicated picture for $\mathrm{N}$ is discussed by Thingstad \& Lignell (1997). To our knowledge, this is the first time this difference has been documented for natural communities, and it supports the emerging conclusion that $\mathrm{P}$ - and C-limitation is more common than N-limitation for limnetic and marine heterotrophic planktonic bacteria (Vadstein 2000, Church 2008, Vadstein 2011). Re-mineralisation by heterotrophic bacteria is hard to quantify, but the negative linear relationship between percent re-mineralisation and percent inorganic uptake has the potential to be used for indirect estimation.

\section{Do DOC, DON and DOP accumulate due to higher production than consumption, and what is the turnover time of these resources?}

It has been claimed that, during summer, DOC in marine waters may accumulate due to 'a malfunctioning microbial loop' in the restricted sense that not all degradable DOC released from the food web can 
be consumed (Thingstad et al. 1997). The observed accumulation rates of DOC at moderate to high loadings of nutrients is in accordance with the observation that DOC concentrations may double during the summer period, and our data support the suggestion that there is a threshold nutrient loading to the system above which DOC accumulates (Thingstad et al. 1997). As we see it, the expression 'malfunctioning microbial loop' may be misleading, as DOC accumulation is probably a normal phenomenon reflecting an imbalance in $\mathrm{C}: \mathrm{N}: \mathrm{P}$ ratios, due to an imbalance between resources consumed and required by the phagotrophic heterotrophs (Olsen et al. 2011).

The fact that DOP accumulates in the water at even higher rates than DOC at the 2 highest nutrient loadings is notable, as $\mathrm{P}$ is a nutrient in high demand (Olsen et al. 2011; and see 'Results'). It may be speculated that the cost of production of exoenzymes like alkaline phosphatase is high, or that enzymatic breakdown of DOP is low due to poor accessibility of enzymes to the substrate. The latter may be due to the tertiary structure of the substrate or complexion with other molecules, such as proteins. Conan et al. (2007) found low production of DOP under P-limited conditions, whereas more than three-quarters of the assimilated DIP were converted to DOP under surplus DIP conditions. Our result that DON did not accumulate replicates previous findings (Conan et al. 2007), and could be interpreted as signifying that $N$ is a limiting nutrient. However, in this study, this was contradicted by the fact that the heterotrophic bacteria acted as mineralisers of $\mathrm{N}$. An alternative explanation may be that $\mathrm{C}$ in the DON was of highest value than the $N$, either as building blocks or as energy, and this resulted in an overconsumption of N (Thingstad \& Lignell 1997).

It was striking that turnover time of DOC varied by a maximum factor of 7 and with an overall range of 11 to $85 \mathrm{~d}$. This is in contrast to the ${ }^{14} \mathrm{C}$-based dating of DOC, which indicate an average age of $>1000 \mathrm{yr}$ for this chemical mixture. Williams \& Druffel (1987) calculated that approximately one half was young $(<30 \mathrm{yr})$ and the other old $(>6000 \mathrm{yr})$, and Wang et al. (2006) found that the age varied by orders of magnitude in the chemical fraction from modern to $>25000$ yr. These datings are in contrast to previous chemical measurements showing turnover of $>2$ mo (Kirchman et al. 1991, Olsen et al. 2002, Vadstein et al. 2003). This discrepancy may be methodological or related to the presence of some very old DOC. In contrast to our data, Kirchman et al. (1991) found indications of slow turnover of DON but, as in the present study, that DON had a longer turnover time than
DOC (and DOP). Our data and the chemical-based studies cited above provide strong evidence of DOC, DON and DOP as highly dynamic pools with turnover rates ranging from a few weeks to a few months.

\section{Are $\mathbf{C}, \mathbf{N}$ and $\mathbf{P}$ budgets proportionally identical representations, or do the 3 elements show element specific characteristics?}

This question may seem paradoxical, but the proportional identity of $\mathrm{C}, \mathrm{N}$ and $\mathrm{P}$ budgets is an assumption used in many situations including conversion from one element to another (e.g. C to $\mathrm{N}$ ) and in numeric modelling. Our data suggest that the $\mathrm{C}, \mathrm{N}$ and $\mathrm{P}$ budgets have strong similarities, but also elementspecific characteristics. Moreover, the $\mathrm{N}$ budget seems to be intermediary between the $\mathrm{C}$ and the $\mathrm{P}$ budgets, and a classification according to mineral nutrients versus energy/carbon is therefore not possible.

Heterotrophic bacteria were important re-mineralisers of $\mathrm{C}$ (average $35 \%$ of total respiration), with some contribution to the re-mineralisation of $\mathrm{N}$ $(12 \%)$ and none to the re-mineralisation of P. In contrast, heterotrophic bacteria competed strongly with autotrophs for DIP, and their uptake was -8 to $34 \%$ (mean 18\%) of the total DIP uptake in spite the fact that the biomass of heterotrophic bacteria as a percentage of autotrophic biomass spanned only 5 to $21 \%$ (mean $11 \%$ ) within the nutrient loading gradient. The competition with autotrophs for DIN was of significance only under oligotrophic (zero nutrient loading) conditions. As food particles, the significance of heterotrophic bacteria was small for overall productivity on a C-basis. However, as $\mathrm{N}$ - and especially P-rich food particles for protozoa, heterotrophic bacteria had a strong impact on the re-mineralisation on $\mathrm{N}$ and $\mathrm{P}$, since on average grazers of bacteria were responsible for one-third of the DIN and two-thirds of the DIP produced. The consequences of the fact that heterotrophic bacteria are food particles rich in $\mathrm{N}$ (Gismervik et al. 1996) and P (Vadstein 2000) is only recognised to a limited extent in plankton ecology, in spite of the fact that this was established for P almost 20 yr ago (Vadstein et al. 1993).

The differences in the roles of heterotrophic bacteria in the cycling of $\mathrm{C}, \mathrm{N}$ and $\mathrm{P}$ is also illustrated in the calculations of their trophic position on a C-, Nand P-basis, with significant differences in the averages for all three. The fact that heterotrophic bacteria were more than 2 trophic levels above the copepods is striking. In some previous studies, heterotrophic 
bacteria have, arbitrarily, been given a fixed trophic position of 2 (e.g. Azam et al. 1983), which can give a misleading impression of their functional role in the $\mathrm{C}$ cycle. The fact that, compared to the C-based estimates, the estimates on a $\mathrm{N}$ - and P-basis are on average 1 and 2 trophic levels lower, respectively, clearly demonstrates the limited impact of heterotrophic bacteria in re-mineralisation and their role as competitors for inorganic $\mathrm{N}$ and especially $\mathrm{P}$.

\section{CONCLUSIONS}

The present study is a first attempt to make a complete estimation of $\mathrm{C}, \mathrm{N}$ and $\mathrm{P}$ fluxes of relevance for heterotrophic bacteria within a nutrient loading gradient, and to evaluate the functional consequences for the planktonic food web. The inverse modelling approach seems to be a strong tool for estimating fluxes that today are impossible to quantify. Moreover, it seems less vulnerable to bias than traditional budget calculations.

Heterotrophic bacteria had a low impact on productivity at higher trophic levels, in spite the fact that DOC consumption by heterotrophic bacteria was between 40 and $240 \%$ of autotrophic production (mean 91\%), for which bacteria themselves produced approximately half of the DOC. Whether the DOC produced from bacteria was due to excretion or viral lysis was not clarified, but likely both mechanisms contributed. The most significant function of heterotrophic bacteria in the $\mathrm{C}$ cycle seemed to be re-mineralisation $\left(\mathrm{CO}_{2}\right.$ production), which is in accordance with the old paradigm. The turnover of DOC seems to be orders of magnitude faster than indicated by ${ }^{14} \mathrm{C}$ dating, and DOC accumulated at all except the lowest nutrient loadings.

Heterotrophic bacteria have completely different roles in the cycling of $\mathrm{N}$ and $\mathrm{P}$, with a role in $\mathrm{N}$ cycling intermediary to $\mathrm{C}$ and $\mathrm{P}$. Heterotrophic bacteria were a major competitor with the autotrophs for DIP, and the DIP and DOP uptake was similar. Heterotrophic bacteria never acted as re-mineralisers of $\mathrm{P}$, and were likely P-limited in spite the fact that DOP accumulated more than DOC at high nutrient loading. Thus, their role in $\mathrm{P}$ cycling was not in accordance with the old paradigm, and their major role as re-mineralisers of $\mathrm{P}$ is an indirect one as $\mathrm{P}$-rich food particles for protozoa, which acted as the main remineralisers. Strangely, the significance of DIN as an $\mathrm{N}$ source decreased with increasing DIN load, and was insignificant at the 3 highest nutrient loadings. Thus, heterotrophic bacteria competed significantly with autotrophs for DIN only with zero nutrient loading. Conversely, heterotrophic bacteria were in general re-mineralisers of $\mathrm{N}$, but contributed on average only $12 \%$ to the total production of DIN (range 0 to $17 \%)$. As in the case of $\mathrm{P}$, the main role of heterotrophic bacteria for re-mineralisation of $\mathrm{N}$ was an indirect one as N-rich food particles for protozoa that were the main mineralisers. DON did not accumulate, which was probably due to the high C-value of $\mathrm{N}$-rich DOM. The role of heterotrophic bacteria in $\mathrm{N}$ cycling did not contradict the old paradigm, but their significance as re-mineralisers was minor. The differences in the role of heterotrophic bacteria in the cycling of $\mathrm{N}$ and $\mathrm{P}$ were likely due to the differences between how these 2 elements are linked to DOC, and to the relatively high $\mathrm{P}$ requirements compared to $\mathrm{N}$ requirements of heterotrophic bacteria.

The above conclusions were obtained under conditions with a balanced N:P ratio in the nutrient supply, and should therefore be of relevance for most full salinity areas. The responses are likely to be modified under skewed N:P ratios, as observed in most freshwater influenced systems.

Acknowledgements. The experimental work was undertaken by the Norwegian partners in COMWEB, a project of the ELOISE Programme that was funded by the EC MAST Programme (MAST3-CT96-0052). The Research Council of Norway contributed to the final scientific treatment and publishing. The comprehensive base of data used in this paper is the result of the hard work of all the enthusiastic project participants involved in the experiments carried out in Hopavågen, Central Norway, in August and September 1997. Thanks to M. Yufera and other colleagues at the Instituto de Ciencias Marinas de Andalucia (Cadiz, Spain) for allowing the first author to write this paper in a friendly and peaceful atmosphere.

\section{LITERATURE CITED}

Azam F, Fenchel T, Field JG, Gray JS, Meyer-Reil LA, Thingstad F (1983) The ecological role of water-column microbes in the sea. Mar Ecol Prog Ser 10:257-263

Bell RT (1993) Estimating production of heterotrophic bacterioplankton via incorporation of tritiated thymidine. In: Kemp PF, Sherr BF, Sherr EB, Cole JJ (eds) Handbook of methods in aquatic microbial ecology. Lewis Publishers, Boca Raton, FL, p 495-504.

Biddanda B, Benner R (1997) Carbon, nitrogen, and carbohydrate fluxes during the production of particulate and dissolved organic matter by marine phytoplankton. Limnol Oceanogr 42:506-518

Booth BC (1993) Estimating cell concentrations and biomass of autotrophic plankton using microscopy. In: Kemp PF, Sherr BF, Sherr EB, Cole JJ (eds) Handbook of methods in aquatic microbial ecology. Lewis Publishers, Boca Raton, FL, p 199-205 
Børsheim KY, Bratbak G (1987) Cell volume to cell carbon conversion factors for a bacterivorous Monas sp. enriched from seawater. Mar Ecol Prog Ser 36:171-175

Børsheim KY, Olsen Y (1984) Grazing activities by Daphnia pulex on natural populations of bacteria and algae. Verh Internat Verein Limnol 22:644-648

Børsheim KY, Vadstein O, Myklestad SM, Reinertsen H, Kirkvold S, Olsen Y (2005) Photosynthetic algal production, accumulation and release of phytoplankton storage carbohydrates and bacterial production in a gradient in daily nutrient supply. J Plankton Res 27:743-755

Breibart M, Middelboe M, Rohwer F (2008) Marine viruses: community dynamics, diversity and impact on microbial processes. In: Kirchman DL (ed) Microbial ecology of the ocean. Wiley-Liss, Hoboken, NJ, p 443-479

Church MJ (2008) Resource control of bacterial dynamics in the sea. In: Kirchman DL (ed) Microbial ecology of the ocean. Wiley-Liss, Hoboken, NJ, p 335-382

> Conan P, Søndergaard M, Kragh T, Thingstad F and others (2007) Partitioning of organic production in marine plankton communities: The effects of inorganic nutrient ratios and community composition on new dissolved organic matter. Limnol Oceanogr 52:753-765

Dafner EV, Wagersky DJ (2002) A brief overview of modern directions in marine DOC studies Part II-Recent progress in marine DOC studies. J Environ Monit 4: 55-69

> De Laender F, Van Oevelen D, Soetaert K, Middelburg JJ (2010) Carbon transfer in herbivore- and microbial loopdominated pelagic food webs in the southern Barents Sea during spring and summer. Mar Ecol Prog Ser 398: 93-107

del Giorgio PA, Cole JJ (2000) Bacterial energetics and growth efficiency. In: Kirchman DL (ed) Microbial ecology of the oceans. Wiley-Liss, Hoboken, NJ, p 289-325

> Ducklow HW, Purdie DA, Williams PJL, Davies JM (1986) Bacterioplankton: a sink for carbon in a coastal marine plankton community. Science 232:865-867

Elser JJ, Bracken MES, Cleland EE, Gruner DS and others (2007) Global analysis of nitrogen and phosphorus limitation of primary producers in freshwater, marine and terrestrial ecosystems. Ecol Lett 10:1135-1142

- Fenchel T (1982) Ecology of heterotrophic microflagellates. IV. Quantitative occurrence and importance as bacterial consumers. Mar Ecol Prog Ser 9:35-42

> Gismervik I, Andersen T, Vadstein O (1996) Pelagic food webs and eutrophication of coastal waters: impact of grazers on algal development. Mar Pollut Bull 33:22-35

Gismervik I, Olsen Y, Vadstein O (2002) Micro- and mesozooplankton response to enhanced nutrient input-a mesocosm study. Hydrobiologia 484:75-87

Granum E, Kirkvold S, Myklestad SM (2002) Cellular and extracellular production of carbohydrates and amino acids by the marine diatom Skeletonema costatum: diel variations and effects of N-depletion. Mar Ecol Prog Ser 242:83-94

- Jackson GA, Eldridge PM (1992) Food web analysis of a planktonic system off southern California. Prog Oceanogr 30:223-251

Johannes RE (1968) Nutrient regeneration in lakes and oceans. Adv Microbiol Sea 1:203-313

Jürgens K, Massana R (2008) Protistan grazing on marine bacterioplankton. In: Kirchman DL (ed) Microbial ecology of the ocean. Wiley-Liss, Hoboken, NJ, p 383-441

Kawasaki N, Benner R (2006) Bacterial release of dissolved organic matter during cell growth and decline: molecular origin and composition. Limnol Oceanogr 51:2170-2180 Kirchman DL (2008) Microbial ecology of the ocean. WileyLiss, Hoboken, NJ

Kirchman DL, Suzuki Y, Garside C, Ducklow HW (1991) High turnover rates of dissolved organic-carbon during a spring phytoplankton bloom. Nature 352:612-614

Kones JK, Soetaert K, van Oevele D, Owin JO, Mavuti K (2006) Gaining insight into food webs reconstructed by the inverse method. J Mar Syst 60:153-166

Lean DRS, Nalewajko C (1976) Phosphate exchange and organic phosphorus excretion by freshwater algae. J Fish Res Bd Can 33:1312-1323

Lønborg C, Alvarez-Salgado XA, Davidson K, Miller AEJ (2009) Production of bioavailable and refractory dissolved organic matter by coastal heterotrophic microbial populations. Estuar Coast Shelf Sci 82:682-688

Madigan MT, Martinko JM, Dunlap PV, Clark DP (2009) Brock biology of microorganisms, 12th edn. Pearson, San Francisco, CA

McCarthy MD, Hedges JI, Benner R (1998) Major bacterial contribution to marine dissolved organic nitrogen. Science 281:231-234

Ogawa H, Amagai Y, Koike I, Kaiser K, Benner R (2001) Production of refractory dissolved organic matter by bacteria. Science 292:917-920

> Olsen Y (1989) Evaluation of competitive ability of Staurastrum luetkemuellerii (Chlorophyceae) and Microcystis aeruginosa (Cyanophyceae) under P limitation. J Phycol 25:486-499

> Olsen Y, Vårum KM, Jensen A (1986) Some characteristics of the carbon compounds released by Daphnia. J Plankton Res 8:505-517

Olsen Y, Vadstein O, Jensen A, Andersen T (1989) Competition between Staurastrum luetkemullerii (Chlorophycae) and Microcystis aeruginosa (Cyanophycae) under varying modes of phosphate supply. J Phycol 25:499-508

> Olsen LM, Reinertsen H, Vadstein O (2002) Can phosphorus limitation inhibit dissolved organic carbon consumption in aquatic microbial food webs? A microcosm study. Microb Ecol 43:353-366

> Olsen Y, Agusti S, Andersen T, Duarte CM and others (2006) A comparative study of responses in planktonic food web structure and function in contrasting European coastal waters exposed to experimental nutrient addition. Limnol Oceanogr 51:488-501

> Olsen Y, Andersen T, Gismervik I, Vadstein O (2007) Protozoan and metazoan zooplankton-mediated carbon flows in nutrient-enriched coastal planktonic communities. Mar Ecol Prog Ser 331:67-83

> Olsen Y, Andersen T, Gismervik G, Vadstein O (2011) Marine heterotrophic bacteria, protozoan and metazoan zooplankton may experience protein $\mathrm{N}$ or mineral P limitation in coastal waters. Mar Ecol Prog Ser 436:81-100

> Pirt SJ (1982) Maintenance energy: a general model for energy-limited and energy-sufficient growth. Arch Microbiol 133:300-302

Putt M, Stoecker DK (1989) An experimentally determined carbon:volume ratio for marine 'oligotrichous' ciliates from estuarine and coastal waters. Limnol Oceanogr 34: 1097-1103

Robinson C (2008) Heterotrophic bacterial respiration. In: Kirchman DL (ed) Microbial ecology of the ocean. WileyLiss, Hoboken, NJ, p. 299-334

Sherr E, Sherr B (2008) Understanding roles of microbes in 
marine pelagic food webs: a brief history. In: Kirchman DL (ed) Microbial ecology of the ocean. Wiley-Liss, Hoboken, NJ, p. 27-44

Sherr BF, Sherr EB, Berman T (1982) Decomposition of organic detritus: a selective role for microflagellate protozoa. Limnol Oceanogr 27:765-769

Smith EM, Prairie YT (2004) Bacterial metabolism and growth efficiency in lakes: the importance of phosphorus availability. Limnol Oceanogr 49:137-147

Stone L, Berman T, Bonner R, Barry S, Weeks SW (1993) Lake Kinneret: a seasonal model for carbon flux through the planktonic biota. Limnol Oceanogr 38:1680-1695

Strathmann RR (1967) Estimating the organic carbon content of phytoplankton from cell volume or plasma volume. Limnol Oceanogr 12:411-418

Strayer D (1988) On the limits to secondary production. Limnol Oceanogr 33:1217-1220

Strom SL, Benner R, Ziegler S, Dagg MJ (1997) Planktonic grazers are a potentially important source of marine dissolved organic carbon. Limnol Oceanogr 42:1364-1374

Thingstad TF (2000) Elements of a theory for the mechanisms controlling abundance, diversity, and biogeochemical role of lytic bacterial viruses in aquatic systems. Limnol Oceanogr 45:1320-1328

Thingstad TF, Lignell R (1997) Theoretical models for the control of bacterial growth rate, abundance, diversity and carbon demand. Aquat Microb Ecol 13:19-27

Thingstad TF, Hagström A, Rassoulzadegan F (1997) Accumulation of degradable DOC in surface waters: Is it caused by a malfunctioning microbial loop? Limnol Oceanogr 42:398-404

Ulanowicz RE (1986) Growth and development: ecosystems phenomenology. Springer, Berlin

Vadstein O (1998) Evaluation of competitive ability of two heterotrophic planktonic bacteria under phosphorus limitation. Aquat Microb Ecol 14:119-127

Vadstein O (2000) Heterotrophic, planktonic bacteria and cycling of phosphorus: phosphorus requirements, competitive ability and food web interactions. Adv Microb Ecol 16:115-168

Vadstein O (2011) Large variation in growth-limiting factors for marine heterotrophic bacteria in the Arctic waters of

Editorial responsibility: Graham Savidge, Portaferry, UK
Spitsbergen $\left(98^{\circ} \mathrm{N}\right)$. Aquat Microb Ecol 63:289-297

Vadstein O, Olsen Y (1989) Chemical composition and phosphate-uptake kinetics of limnetic bacterial communities cultured under phosphorus limitation. Limnol Oceanogr 34:939-946

Vadstein O, Harkjerr BO, Jensen A, Olsen Y, Reinertsen H (1989) Cycling of organic carbon in the photic zone of a eutrophic lake with special reference to the bacteria. Limnol Oceanogr 34:840-855

> Vadstein O, Jensen A, Olsen Y, Reinertsen H (1993) The role of planktonic bacteria in phosphorus cycling in lakes Sink and link. Limnol Oceanogr 38:1539-1544

- Vadstein O, Olsen LM, Busch A, Andersen T, Reinertsen HR (2003) Is phosphorus limitation of heterotrophic bacteria and accumulation of degradable DOC a normal phenomenon in phosphorus limited systems? A microcosm study. FEMS Microbiol Ecol 46:307-316

van Oevelen D, Van den Meersche K, Meysman FJR, Soetaert K, Middelburg JJ, Vézina AF (2010) Quantifying food web flows using linear inverse models. Ecosystems (N Y) 13:32-45

Verity PG, Sieracki ME (1993) Use of colour image analysis and epifluorescence microscopy to measure plankton biomass. In: Kemp PF, Sherr BF, Sherr EB, Cole JJ (eds) Handbook of methods in aquatic microbial ecology. Lewis Publishers, Boca Raton, FL, p 327-337

Vézina AF (1989) Construction of flow networks using inverse methods. In: Wulff F, Field JG, Mann KH (eds) Network analysis in marine ecology. Methods and applications. Springer, p 62-81

Vézina AF, Platt T (1988) Food web dynamics in the ocean. I. Best-estimates of flow networks using inverse methods. Mar Ecol Prog Ser 42:269-287

Wang XC, Callahan J, Chen RF (2006) Variability in radiocarbon ages of biochemical compound classes of high molecular weight dissolved organic matter in estuaries. Estuar Coast Shelf Sci 68:188-194

- Weinbauer MG (2004) Ecology of prokaryotic viruses. FEMS Microbiol Rev 28:127-181

- Williams PM, Druffel ERM (1987) Radiocarbon in dissolved organic matter in the central north pacific-ocean. Nature 330:246-248

Submitted: June 16, 2011; Accepted: October 29, 2011

Proofs received from author(s): January 30, 2012 